\title{
Impact of Over-exploitation in Coastal Groundwater on the Variations in Submarine Groundwater Discharge Rate in a Complex Two Aquifer System by Finite Element Modelling: A Case Study From South India
}

\section{Sundara Pandian Rajaveni}

Mepco Schlenk Engineering College

\section{Sumadevi Nair Indu}

Anna University Chennai

\section{Karthikeyan Brindha}

Freie Universität Berlin: Freie Universitat Berlin

Lakshmanan Elango ( $\nabla$ elango34@hotmail.com )

Anna University https://orcid.org/0000-0002-6692-5773

\section{Research Article}

Keywords: coastal aquifer, finite element model, FEFLOW, seawater intrusion, check dams, managed aquifer recharge, Chennai

Posted Date: March 16th, 2021

DOI: https://doi.org/10.21203/rs.3.rs-259927/v1

License: (c) (1) This work is licensed under a Creative Commons Attribution 4.0 International License. Read Full License

Version of Record: A version of this preprint was published at Environmental Science and Pollution Research on July 12th, 2021. See the published version at https://doi.org/10.1007/s11356-021-15219-0. 


\title{
Impact of over-exploitation in coastal groundwater on the variations in
} submarine groundwater discharge rate in a complex two aquifer system by

\section{finite element modelling: A case study from south India}

\author{
Sundara Pandian Rajaveni ${ }^{1}$, Sumadevi Nair Indu ${ }^{2}$, Karthikeyan Brindha ${ }^{3}$ and Lakshmanan Elango ${ }^{2}$ * \\ ${ }^{1}$ Department of Civil Engineering, Mepco Schlenk Engineering College, Sivakasi -626005, Tamil Nadu, India \\ ${ }^{2}$ Department of Geology, Anna University, Chennai - 600025, Tamil Nadu, India \\ ${ }^{3}$ Hydrogeology Group, Institute of Geological Science, Freie Universität Berlin, 12249 Berlin, Germany \\ * Corresponding author email: elango@ annauniv.edu
}

\begin{abstract}
The purpose of this study is to understand the impact of coastal groundwater over-exploitation on the variations in submarine groundwater discharge (SGD) flux rate and seawater exchange flux across the seabed. As a case study, numerical modelling techniques were applied to a complex multi-aquifer system located north of Chennai, India, which has been affected since the mid-1970s by overexploitation and seawater intrusion. Because of the relatively high hydraulic conductivity, the model shows a higher amount of seawater inflow in the central part of the region. From 2000 to 2012 , the movement of seawater has increased from $17,000 \mathrm{~m}^{3} /$ day to $24,500 \mathrm{~m}^{3} /$ day due to groundwater overexploitation from the semi-confined aquifer.
\end{abstract} However, the quantum of flux from the sea to the aquifer has been reduced from the year 2006 due to the termination of pumping from a well field supplying a part of the city's water supply. Model simulations show that fresh groundwater of $43,312 \mathrm{~m}^{3} /$ day and saltwater of 43,815 $\mathrm{m}^{3} /$ day will be discharged to the aquifer by the end of 2030 . In addition to the prevailing condition, various management scenarios were also predicted to prevent the degradation of groundwater quality due to seawater intrusion. By adopting managed aquifer recharge methods, saltwater intrusion (rate of $4408 \mathrm{~m}^{3} /$ day) can be reduced and SGD (rate of $22414 \mathrm{~m}^{3} /$ day) rate 
increased. Findings from this study are expected to enhance the understanding of SGD and freshwater budget in coastal areas and in creating integrated coastal management plans.

Keywords: coastal aquifer; finite element model; FEFLOW; seawater intrusion; check dams; managed aquifer recharge; Chennai

\section{Introduction}

Submarine groundwater discharge (SGD) is the mechanism by which all fluids (i.e. fresh groundwater, seawater, or a combination of fresh groundwater and seawater) flow from the seabed to the sea through subsurface geological formation. It includes ocean processes such as convection, tidal pumping, and wave set-up. SGD can release terrestrial nutrients, heavy metals, dissolved solids and other potentially harmful contaminants to the coastal environment (Finkl and Krupa 2003, Taniguchi et al. 2002). This process provides a pathway for terrestrial pollutants that can considerably affect the coastal ecosystems where groundwater discharges. The concentration of pollutants in the nearshore water and their effect on the chemistry and biology of the region depends not only on the fluxes of pollutants, but also on the strength of the mixing process and the exchange with the open ocean. The amount of SGD varies spatially and temporally because of variations in recharge, tides, density, hydraulic gradient, complexity and heterogeneity of aquifer formation (Bokuniewicz et al. 2003). Globally, 90 percent of the SGD is estimated to be recirculated by seawater and the remaining 10 percent is SGD freshwater (Kwon et al. 2014). Thus, in order to assess whether SGD is of specific significance, coastal zone managers need to estimate the extent of SGD and the degree of mixing and interaction between the nearshore sea and the open ocean. 
Research on SGD has received increased attention since the 1990's as the significance of SGD on coastal zone management was understood and many different investigation methods for quantifying SGD were developed (Moosdorf and Oehler 2017, Taniguchi et al. 2019). Several studies have been carried out to quantify the rate of SGD on the coastal environment based on direct measurements (seepage meter, piezometer, calculation of water budget and Darcy Law) and indirect measurements such as geophysical tracers (conductivity signature, salinity, temperature profiling), separation of hydrographs, natural tracer techniques (radium and radon), geochemical tracers (methane, dissolved silicon, ${ }^{228} \mathrm{Th}$, silica), natural radioactive isotopes $\left({ }^{3} \mathrm{H},{ }^{4} \mathrm{He}\right)$, stable isotopes $\left({ }^{2} \mathrm{H},{ }^{18} \mathrm{O},{ }^{87} \mathrm{Sr} /{ }^{88} \mathrm{Sr}\right)$, thermal imaging, GIS topology, theoretical calculations and numerical models.

Numerical modelling is an important tool used to quantify the amount of fresh groundwater discharge to sea and is being increasingly used recently (George et al. 2018, Welch et al. 2019, Vollberg et al. 2019). These models include the aquifer's nearshore terrestrial portion as well as the marine part below the seafloor, where the effects of density are significant. Detailed understanding of geometry and composition of the aquifer is necessary for successful characterization of an aquifer for SGD modelling (Virtasalo 2019). Fresh submarine groundwater was simulated by using variable-density flow and transport models for understanding complex groundwater flow processes in coastal environments (Langevin 2003) In coastal groundwater systems, Luijendijk et al. (2020) simulated submarine and terrestrial groundwater discharge using a numerical model of combined density-driven groundwater flow and solvent transport that solved the equations of fluid flow and solute transport and the equations of state for fluid density and viscosity in a two-dimensional subsurface cross-section. 
India has a long coastline of $7,500 \mathrm{~km}$, and interaction between the freshwater and saline water in these coastal zones are continuous. Several studies have been undertaken in India to learn about the extent of the seawater intrusion and have analyzed the water quality problems in specific locations. Compared to a long coastline of 7,500 km, the number of studies on SGD carried out is less. A summary of the SGD studies carried out in India is given in Table 1. In the present situation, where water shortage is reported in several Indian cities (Pathak 2019), quantification of SGD is important as the groundwater loss in large amounts through the extensive coastline can be used to meet the water requirements for drinking and irrigation (Jacob et al. 2009). With this limited three-dimensional modelling studies on SGD, the understanding of the processes and flux of groundwater from the coastal aquifer to the sea through seabed is also limited. Here, a complex multiple coastal aquifer is used as a case study to simulate the temporal exchange rate of SGD from the coastal freshwater aquifer to sea through the seabed.

\section{Methodology}

\section{Description of the study area}

The study was carried out in a seawater intruded coastal aquifer which is in the AraniKorttalaiyar (A-K) river basin, Tamil Nadu, India (Fig. 1), north of the Chennai City. The Arani river originates at Sadasivakonda in Chittoor district, Andhra Pradesh and it joins the Bay of Bengal in Tamil Nadu. The Korttalaiyar river originates near Pallipattu in Thiruvallur district, Tamil Nadu, and flowing in the southern part of the study area, it supplies water to Chozhavaram reservoir and Red Hills lake, thereafter, flows into the Bay of Bengal. Seawater enters these rivers at a distance of about $5 \mathrm{~km}$ from the coast when the river does not carry freshwater which was observed during the field survey. The southwestern side of the study area is bounded by the Palar river. This region experiences a very dry period during April to June 
100

101

102

103

104

105

106

107

108

109

110

111

112

113

114

115

116

117

118

119

120

121

122

123

124

(summer) with a maximum temperature ranging from $32^{\circ} \mathrm{C}$ to $44^{\circ} \mathrm{C}$ and a colder period from

December to January (winter) when the temperature ranges from $23^{\circ} \mathrm{C}$ to $30^{\circ} \mathrm{C}$. Precipitation in this region depends on southwest (July to September) and northeast (October to December) monsoons. The average annual rainfall is around $1200 \mathrm{~mm}, 35 \%$ of which occurs during the southwest monsoon (July - September) and 60\% during the northeast monsoon (October December). The topography of this area ranges from sea level $(0 \mathrm{~m})$ to $133 \mathrm{~m}$ above mean sea level. This area is dominated by dentritic to sub-dentritic drainage pattern mainly dependent on the geological formation. Six wellfields are located in the buried paleo-channel of Palar river (Fig. 1). The tube wells from these wellfields supply water to Chennai, the capital city of Tamil Nadu, located $45 \mathrm{~km}$ south of the study area. Agriculture is largely practised and the principal crops grown in this area are rice, sugarcane, banana, vegetables, watermelon, tapioca, pearl millet, cluster bean and pulses such as groundnut, sesame and maize.

\section{"Insert Figure 1"}

\section{Data collection and field investigation}

Survey of India (SOI) toposheets (Scale 1: 25,000) covering the study area were used to prepare the base map. Borehole logs of the study area were collected from the Chennai Metropolitan Water Supply and Sewerage Board (CMWSSB) to characterize the aquifer system. Groundwater head and groundwater abstraction rate from the pumping wells in the wellfield was collected from CMWSSB for the period from January 1990 to December 2012. These pumping wells penetrate more than $30 \mathrm{~m}$ depth below ground level which is located in a semiconfined aquifer (shown in Fig. 1). Additionally, the groundwater head from 27 monitoring wells was obtained from the Tamil Nadu Public Works Department (TNPWD) for the calibration of the model (from January 1990 to December 2012). The monthly rainfall from 9 
rain gauge stations was also obtained from the TNPWD for the time period from January 1990 to December 2012.

A well inventory survey was carried out for 60 wells during January 2011 to locate additional groundwater level monitoring wells for the collection of primary data. Based on this survey, 27 dug wells and 22 tube wells were selected as representative wells for regular monitoring of groundwater heads. Groundwater head was measured once in two months from January 2011 to December 2013 by using a water level indicator (Solinist 101). In addition to regular monitoring of groundwater head, an intensive field investigation was carried out to measure the groundwater head in several dug and tube wells located very close to each other for characterizing the aquifer system. They dug wells in this area are generally less than $20 \mathrm{~m}$ deep and tube wells are up to $120 \mathrm{~m}$ deep. About 20 pairs of dug and tube wells located next to each other were chosen to measure groundwater head. In order to convert the groundwater head measured below ground level with respect to the sea level, the elevation of the ground surface was measured using a Differential Global Positioning System (DGPS) (Leica GS09 GNSS).

\section{Geological investigations}

Geologically, this area comprises rocks from Archaean to Quaternary age. Crystalline rocks of Archaean age comprising of gneiss and charnockite form the basement. The Upper Gondwana series of shale and clay deposits lie over these crystalline rocks. Tertiary and Quaternary formation lies over the Upper Gondwana formation of a massive pile of lacustrine and fluvial deposits (Rao et al. 2004b). The tertiary formation consists of shale, clay, sandstone and marine sediments. The quaternary formation comprises of laterite and alluvium deposits. Alluvial deposits consist of sand, silt, sandy clay, gravel and pebbles which mostly occur along with the 
Arani and Korttalaiyar river courses (Fig. 2a). Sand is the dominant fraction in the alluvial and aeolian deposits which occurs near the coast.

The geological map of the area obtained from the Geological Survey of India (GSI) in 1:50,000 scale was updated by interpreting the IRS 1D LISS-III imagery (2006) of $23.5 \mathrm{~m}$ spatial resolution. During the field visit the identified outcrops were cross-checked with the geology map prepared from LISS-III imagery, then it was validated through outcrops. The northwestern and southeastern part of the area is covered by laterite, sandstone and conglomerate. Lineaments play an important role in the groundwater flow. Most of the lineaments are aligned along the west-east direction in the western and central parts of the study area (UNDP 1987). A major fault (74 km length) is identified from the north of Ponneri to Keshavaram running in NE-SW direction (UNDP 1987). Another major fault is inferred running along with the eastern contact between the crystalline and sedimentary formations. Arani and Korttalaiyar rivers for certain distances are aligned along the faults (Rajaveni 2015).

\section{Hydrogeological investigations}

The alluvial deposits are characterized by a number of clay lenses and therefore the deposit is divided into two water-bearing layers i.e. clay and sandy clay of approximately 3 to $5 \mathrm{~m}$ thickness which extends up to a distance of $30 \mathrm{~km}$ west of the coast. The geological crosssection was prepared based on the lithology collected from the CMWSSB. Based on the lithology, field investigation and groundwater head measurement, two aquifers, one unconfined and one semi-confined were identified which had an extent of $30 \mathrm{~km}$ from the coast. Beyond this distance, the two aquifers merge and become a single aquifer. Fig. 2b shows semiconfining layer acted like a leaky layer which allows groundwater infiltration from unconfined aquifer to semi-confined aquifer (Rajaveni 2015). 
The dug wells in this area are generally less than $20 \mathrm{~m}$ deep and tube wells are up to $120 \mathrm{~m}$ deep. The groundwater head in the unconfined aquifer ranges from 2 to $6 \mathrm{~m} \mathrm{bgl}$ and in the semi-confined aquifer, it ranges from 14 to $20 \mathrm{~m} \mathrm{bgl}$. The water from these wells is used for domestic, irrigational and municipal purposes. The six wellfields located in the alluvial deposits and paleo buried channels have 98 pumping wells. Previous studies by Rao et al. (2004b), and Charalambous and Garratt (2009) on the recharge and abstraction relationship in this region were carried out through finite element model only by considering it as a single confined aquifer system. Due to the interaction between the unconfined and semi-confined aquifer during pumping, it is crucial to consider them as two aquifers in the model. In general, the regional groundwater flow is towards the sea; however, there may be variations in local hydraulic heads due to the difference in pumping pattern.

\section{Modelling of groundwater flow and transport}

Three-dimensional groundwater flow equation in an unconfined aquifer given by Rushton (2003) is:

$$
\frac{\partial}{\partial x}\left(K_{x} \frac{\partial h}{\partial x}\right)+\frac{\partial}{\partial y}\left(K_{y} \frac{\partial h}{\partial y}\right)+\frac{\partial}{\partial z}\left(K_{z} \frac{\partial h}{\partial z}\right)=0
$$

192

Where $\mathrm{K}_{\mathrm{x}}, K_{y}$, and $K_{z}$ are the hydraulic conductivities $\left(\mathrm{LT}^{-1}\right)$ along $\mathrm{x}, \mathrm{y}$ and $\mathrm{z}$-coordinate directions, $h$ is the hydraulic head (L), $\mathrm{x}_{\mathrm{i}}$ is the Cartesian co-ordinates (L). Basic Richards equation is written with these two unknown variables in one balance equation. Finite element model based on the Richards equation is written in the following form which has to be solved either for $\psi$ or s (DHI 2009b). 
Where $\psi$ is the pressure head, $(\psi>0$ saturated medium,

$\psi \leq 0$ unsaturated medium $), \mathrm{s}(\psi)$ is the saturation, $(0<\mathrm{s} \leq 1, \mathrm{~s}=1$ if medium is saturated $), \mathrm{t}$ is relative hydraulic conductivity $\left(0<\mathrm{K}_{\mathrm{r}} \leq 1, \mathrm{~K}_{\mathrm{r}}=1\right.$ if saturated at $\left.\mathrm{s}=1\right), \mathrm{K}$ is tensor of hydraulic conductivity for the saturated medium (anisotrophy), $\chi$ is buoyancy coefficient including fluid density effects, e is gravitational unit vector, $\mathrm{Q}$ is specific mass supply, and $\mathrm{R}$ is residual. This equation was used to simulate the spatial and temporal variation in hydraulic head based on flow between the finite-element cells of the model.

Where $\mathrm{CHEM}=-\rho_{\mathrm{b}} \partial \mathrm{C} / \partial \mathrm{t}$ for linear equilibrium-controlled sorption or ion-exchange reactions. $\mathrm{D}_{\mathrm{ij}}$ is the coefficient of hydrodynamic dispersion, $\left(\mathrm{L}^{2} \mathrm{~T}^{-1}\right), \mathrm{C}^{\prime}$ is the concentration of the groundwater in the source or sink fluid, $\mathrm{C}$ is the concentration of the species adsorbed on the solid (mass of solute/mass of solid), $\rho_{\mathrm{b}}$ is the bulk density of the sediment, $\left(\mathrm{ML}^{-3}\right), \mathrm{V}_{\mathrm{i}}$ is the seepage velocity, $\left(\mathrm{LT}^{-1}\right), \mathrm{W}^{*}$ is the volume flux per unit area, $\left(\mathrm{LT}^{-1}\right)$, and $\varepsilon$ is the effective porosity of the porous medium. The first term on the right side of equation (3) represents the change in concentration due to hydrodynamic dispersion. The second term of equation (3) represents advective transport and it describes the movement of solutes at the average seepage velocity of the groundwater flow. The third term of equation (3) represents the effects of mixing with a source fluid that has a different concentration than the groundwater at the location of the recharge or injection. The fourth term of equation (3) lumps all of the chemical, geochemical, 
and biological reactions that cause transfer of mass between the liquid and solid phases or conversion of dissolved chemical species from one form to another (Konikow 1996).

Three-dimensional density-dependent mass transport is modelled in Finite Element subsurface FLOW (FEFLOW) on the basis of the Darcy law and nonlinear (non-Fickian) dispersion law (DHI 2009b). In the linear Fickian law, the dispersive mass flux of a solute is proportional to the solute concentration gradient. Density coupled flow and transport processes is simulated by following equations (DHI 2009b)

$$
\begin{aligned}
& \frac{\partial(\varepsilon \rho)}{\partial t}+\nabla \cdot(\rho v)=Q_{\rho} \\
& \frac{\partial(\varepsilon C)}{\partial t}+\nabla \cdot\left(C v+J_{C}\right)=Q_{C}
\end{aligned}
$$

Where $\mathrm{C}$ is the concentration, $\left(\mathrm{ML}^{-3}\right), \mathrm{J}_{\mathrm{C}}$ is Fickian mass flux vector, $\left(\mathrm{ML}^{-2} \mathrm{~T}^{-1}\right), \mathrm{p}$ is fluid pressure, $\left(\mathrm{ML}^{-1} \mathrm{~T}^{-2}\right), \mathrm{Q}_{\rho}$ is bulk fluid flow sink/source, $\left(\mathrm{ML}^{-3} \mathrm{~T}^{-1}\right), \mathrm{Q}_{\mathrm{C}}$ is bulk mass sink/source, $\left(\mathrm{ML}^{-3} \mathrm{~T}^{-1}\right), \mathrm{v}$ is Darcy velocity vector, $\left(\mathrm{LT}^{-1}\right), \alpha$ is solute expansion coefficient, $(1), \varepsilon$ is porosity, $\rho$ is fluid density, $\left(\mathrm{ML}^{-3}\right), \mu$ is dynamic viscosity of fluid, $\left(\mathrm{ML}^{-1} \mathrm{~T}^{-2}\right)$.

In the present study, the coastal alluvial aquifer has complex geometry and boundary conditions. SGD is assessed by three-dimensional numerical groundwater flow simulation software of FEFLOW version 6.2. In this method, the area of interest is divided into various irregular triangular shaped elements. It is possible to refine the size of the elements much smaller along the coastal regions where a better accuracy of SGD should be estimated. The unknown value of groundwater head for the different time periods is computed at the triangle intersect nodes. The groundwater head of the interior of each cell is determined by interpolation between the nodal points. 
Model development

\section{Conceptual model development and discretisation}

251

252

253

254

Fig. 1 shows the Arani and Korttalaiyar river basin in which the area considered for the groundwater modelling was delineated based on the geomorphology, geology and hydrogeological conditions. That is, to carry out groundwater modelling, possible aquifer zones with a thickness greater than $10 \mathrm{~m}$ were delineated. The north, south and western boundary of this area side was fixed as the watershed boundary. Even though, the Arani river enters the area considered for the groundwater modelling from the northwest, this was demarcated as the aquifer boundary due to the considerable reduction in the width of the alluvium due to the presence of laterite.

This complex two aquifer system was discretized into nine layers considering the lithological variations observed in the area. The model is developed for $90 \mathrm{~km}$ from the coast. For about $30 \mathrm{~km}$ from the coast, the layer 1 and 2 represent the unconfined aquifer, layer 3 and 4 represent semi-confining layer (aquitard) and layers from 5 to 8 represent the semi-confined aquifer. Beyond $30 \mathrm{~km}$ from the coast, the layers from 1 to 8 represent the single unconfined aquifer. Layer 9 represents the bottom of the aquifer which is impermeable. The model area of 1456 $\mathrm{km}^{2}$ was discretized into finite element mesh consisting of approximately 1.5 million triangular finite element cells (Fig. 3a). The size of the cells initially varies from $0.056 \mathrm{~km}^{2}$ to $0.424 \mathrm{~km}^{2}$. The mesh size was further refined along the river course and around the wellfield areas to estimate the head and solute concentration with finer resolution. The size of the finite element cells in these regions varies from $500 \mathrm{~m}^{2}$ (near well field and river) to $35,000 \mathrm{~m}^{2}$ (far from well 
271 field and river). Fig. 3b shows the north-south cross-section of the groundwater model. Aquifer

272 thickness includes elevation of the top and bottom of the aquifer which was derived from the

273 borehole logs and from previous studies conducted by UNDP (1987). The elevation of the top

274 of the aquifer ranges from $0 \mathrm{~m}$ to $133 \mathrm{~m}$ msl (mean sea level).

\section{Boundary and initial conditions}

279 The eastern side of the area bounded by the Bay of Bengal was considered as a constant head 280 boundary. The northern and southern boundaries are watershed boundaries; they were considered as no-flow conditions. The Palar river is flowing on the southwestern side and hence it is a variable head. The two rivers flowing in this region were considered as river head boundary. To determine the initial groundwater head, the monthly groundwater level data available for 47 wells (Fig. 1) from the year 1990 to 2010 was analyzed. The groundwater head measured during January 1996 was considered as an initial head because it is identified that seawater intrusion during January 1996 was very low with the groundwater head in both the aquifers was zero $\mathrm{m} \mathrm{msl}$ at the coast.

\section{Aquifer Parameters}

Aquifer parameters such as hydraulic conductivity, porosity and specific yield were assigned to each element based on pumping test data (UNDP 1987). The specific yield of the aquifers was obtained from Todd (2001) and Fetter (2001) for different formations. The range of values of aquifer parameters considered for modelling is given in Table 2 . The hydraulic conductivity values from the twenty pumping tests were extrapolated to the area around them by the 
data points. The hydraulic conductivity of the unconfined aquifer varies from $35 \mathrm{~m} /$ day to 100 m/day and for aquitard, it varies from 0.001 to 0.01 (UNDP 1987, TNPWD 2012). Hydraulic conductivity of the semi-confined aquifer (sandy aquifer) varies from $100 \mathrm{~m} /$ day to $250 \mathrm{~m} /$ day (UNDP 1987, TNPWD 2012). The hydraulic conductivity and the thickness of the semiconfined aquifer is higher compared to the unconfined aquifer. The porosity of the aquifer was found in between 0.15 to 0.20 (UNDP 1987). Specific storage values were calculated from the aquifer thickness and storativity which ranges from 0.004 to 0.0009 (Todd 2001, Fetter 2001).

\section{Groundwater recharge and abstraction}

Analysis of the relation between rainfall and groundwater head is one of the methods for estimating groundwater recharge. Rainfall data from 9 raingauge stations were compared with the groundwater head from the monitoring wells located in the unconfined aquifer. The monthly variation in rainfall and groundwater head in the unconfined aquifer from 1996 to 2012 shows the immediate rise in groundwater head after rainfall (Fig. 4). The rise in groundwater head is about $8 \mathrm{~m}$ when the monthly rainfall exceeds $500 \mathrm{~mm}$. The specific yield of the unconfined aquifer is considered to be 15 percent of rainfall in comparison with the groundwater head. Even though, this is an approximate method of estimation of groundwater recharge, the percentage of rainfall recharge determined is comparable with the estimate for this area given by the Groundwater Resources Estimation Committee (GEC 1997).

The variation in groundwater recharge was applied based on the geology and the location of rain gauge stations. The area was divided into 9 Thiessen polygons to define monthly groundwater recharge. Based on the previous studies (Charalambous and Garratt 2009, Anuthaman 2009, GEC 1997) norms, the groundwater recharge was assigned from $10 \%$ to $20 \%$. A return flow from the agricultural field also provides groundwater recharge. 
321 Charalambous \& Garratt (2009) and Anuthaman (2009) stated that almost 39\% of irrigation

322

323 water used in this region returns to the aquifer. Hence, $39 \%$ of pumped water was considered as irrigation return flow. Arani and Korttalaiyar rivers flow only for a few days during the northeast monsoon season (October to December) and the river stage were assigned for river head boundaries.

\section{"Insert Figure 4"}

The indirect method of crop water requirement method was adopted to calculate the groundwater pumping. Advanced techniques of remote sensing and GIS (IRS 1D LISS-III imageries) were applied to prepare land use maps for different seasons. The crop water requirement was estimated from this land use. Groundwater pumping was calculated by multiplying the water requirements of each crop with its corresponding area. The land area was classified into 6 categories such as agriculture, built-up, forest, water bodies, wasteland and wetland.

\section{Results and discussion}

\section{Model calibration and validation}

FEFLOW model was developed to simulate the temporal variation of discharge of submarine groundwater across the seafloor. This model is capable of solving three-dimensional densitydependent flow patterns and recirculated seawater near the seashore and is used to calculate the rate and direction of movement of groundwater through aquifers. The outputs from the model simulation provide information about hydraulic heads and SGD rates for specified hydrogeological conditions. The accuracy of the developed model mainly depends on the availability of exact field data which represents the real world. In order to obtain a reasonably 
accurate representation of field condition, the model was calibrated in steady and transient state conditions.

Steady-state calibration was done by adjusting aquifer parameters within the reported range until the model reproduces observed data close enough. Several trial runs were made to minimize the difference between the observed and the simulated groundwater head. After several runs, the best possible match between the observed and simulated head was achieved when the $\mathrm{R}^{2}$ values for regression line drawn between the two for unconfined and semiconfined aquifer were 0.990 and 0.901 respectively (Fig. 5a and 5b). Then, transient data collected from groundwater recharge and pumping were applied in the FEFLOW model to simulate transient state calibration. Transient state calibration was carried out from January 1996 to December 2003. Transient state calibration was made until the best possible match was obtained between observed and simulated groundwater heads. After the transient state calibration, the $\mathrm{R}^{2}$ values for the regression line were 0.993 and 0.901 between the observed and simulated heads in the unconfined and semi-confined aquifers respectively (Fig. 5c and d). After successful calibration of steady and transient state, validation of the model was carried out by comparing the simulated groundwater head with the observed heads from January 2004 to December 2012 with the input parameters derived from calibration.

$$
\text { "Insert Figure } 5 a \text { and } 5 b "
$$

\section{Flow Simulation}

In order to visualize the impact of over-pumping of this aquifer, a west to the east cross-section from Kannigaipper to the coast, approximately at the center of the aquifer was prepared. The simulated groundwater head in the unconfined and semi-confined aquifers with respect to distance from the sea during January and June for the years 2000, 2005 and 2010 are shown in 
370

371

372

373

Fig. $6 \mathrm{a}$ and $6 \mathrm{~b}$. The severe decline in groundwater head to the level of around $-35 \mathrm{~m}$ msl was noted in the year 2005. This was due to a reduction in recharge as a consequence of low rainfall in the years 2002, 2003 and 2004. This led the groundwater pumped from wells that supply water to the Chennai city become saline. Hence, the groundwater pumping from the Minjur and Panjetti well fields that supply water to the city was stopped in the year 2005. As a result of the termination of pumping from these well fields in 2005 , the groundwater head started to increase, and it is noticed in the year 2010 (Fig. 6a and 6b).

\section{"Insert Figure $6 a$ and $6 b "$}

The total rate of discharge of fresh submarine groundwater along the eastern boundary of the study area from January 1996 to December 2018 in the unconfined and semi-confined aquifers are shown in Fig. 7a and b. Positive values indicate saltwater intrusion and negative values indicates SGD. In the unconfined aquifer, the fresh groundwater was found to be continuously discharged to the sea and the total SGD to the sea was higher during December. That is, a higher amount (of about $60,000 \mathrm{~m}^{3} / \mathrm{day}$ ) of fresh groundwater discharged into sea in postmonsoon compared to the pre-monsoon in the unconfined aquifer. The fresh SGD to the sea is reduced after 2004, Tsunami and it is gradually increased after 2005 flood in this study area. There is a huge increase in fresh SGD in January 2016 because of severe flooding (Gowrisankar et al. 2017) after that it gradually reduced. However, in the semi-confined aquifer, the seawater (positive values) is intruding into the freshwater aquifer due to the over-pumping of groundwater from well fields. The discharge from the sea was comparatively lesser in January than in June. There is a sudden decrease of seawater to the aquifer from the year 1996 to 1998 because the number of check dams constructed since then had increased. 
The fresh SGD along the eastern boundary of the model area from the unconfined and semiconfined aquifers for the months of January and June for the years 2000, 2005 and 2010 are shown in Fig. 8a and b. In the unconfined aquifer, the rate of fresh SGD to the sea is high during January (post-monsoon) than June (pre-monsoon). However, in the semi-confined aquifer, the saline SGD is always moving towards the aquifer. During January, the inflow from the sea is comparatively lesser than in June. In the year 2005, the rate of seawater intruded into the lower aquifer was very high (Fig. 8b).

\section{"Insert Figure $8 a$ and $8 b "$}

\section{Prediction of Submarine Groundwater Discharge}

\section{Baseline scenario}

The baseline scenario is introduced to determine the rate of SGD in the future by assuming annual pumping and recharge will remain constant. This scenario will be helpful to suggest the response of the aquifer and the amount of SGD can be calculated for the long-term if the present condition exists. As explained earlier, the negative values in Fig. 9a indicate fresh SGD. Temporal variation of the SGD rate along the upper aquifer is shown in Fig. 9a. In the unconfined aquifer, the graph shows an increasing trend of fresh SGD for 2030 and the seasonal fluctuation depends on the tendency of the rainfall. Fresh groundwater was predicted to be continuously discharging into the sea. Amount of fresh SGD was greater for the monsoon months (December and January) compared to the summer months (April and May). The simulated results show that the rate of fresh SGD increase by about $43,918 \mathrm{~m}^{3} /$ day during January 2020 and raises to about $61,790 \mathrm{~m}^{3} /$ day during December 2030 . If the present conditions of rainfall recharge and pumping continue in the future, the rate of fresh SGD will increase from 13,459 $\mathrm{m}^{3} /$ day (April 2020) to 14,010 $\mathrm{m}^{3} /$ day (April 2030) during summer. In 
419

420

421

422

423

424

425

426

427

428

429

430

431

432

433

434

435

436

437

438

439

440

441

442

443

the semi-confined aquifer, the baseline scenario shows positive values (Fig. 9b) indicating the seawater movement seawater into the aquifer. This can be reduced from 94,126 $\mathrm{m}^{3} /$ day (Jan 2020 ) to $82,505.5 \mathrm{~m}^{3} /$ day (Jan 2030). It shows a decreasing trend of about $11,418 \mathrm{~m}^{3} /$ day from May 2020 to May 2030. Hence, this baseline scenario itself shows a higher amount of fresh SGD moving into the sea in the unconfined aquifer.

\section{Scenario 1}

Climate change predictions indicate a standard deviation of about $130 \mathrm{~mm}$ in the projected rainfall in the year 2030 (INCCA 2010), which is about $10 \%$ of the present annual rainfall of 1,200 $\mathrm{mm}$. For the projected climate change in the northern parts of Tamil Nadu where the study area is located, the rainfall is likely to increase and the water yield to rise by $10 \%$ to $40 \%$ (INCCA 2010). Hence, scenario 1 was carried out with $10 \%$ increase in rainfall recharge and by continuing the same annual pumping rate. Scenario 1 results also follow a similar trend of rainfall as the baseline scenario (Fig. 9a). In the unconfined aquifer, the rate of fresh SGD increases at an average of about $125 \%$ when compared to the baseline scenario. In the semiconfined aquifer, the rate of recirculated seawater SGD decreases by an average of about $40 \%$ when compared to the baseline scenario. The percentage of fresh SGD rise is greater in the unconfined aquifer compared to the semi-confined aquifer since rainfall exerts higher influence in the unconfined aquifer. In this same aquifer, the groundwater head was rises by about $2 \mathrm{~m}$ in both the aquifer for $10 \%$ increase in rainfall recharge (Rajaveni et al. 2016), which clearly explains the rate of increase of fresh SGD by scenario 1 .

\section{Scenario 2}

Over-pumping of groundwater in this region is experienced over the years to meet the water supply demands of Chennai city (CGWB 2007). The Government is resorting to hiring the 
444 wells owned by farmers in the region to meet the severe water demand in Chennai city over

445 the years (Meijer 2012). The overexploitation of coastal groundwater leads to both submarine 446 groundwater discharge reduction, as well as an increase of seawater inflow and, consequently, 447 an increase of the transition zone thickness (Custodio 2002). Thus, it is essential to understand the changes in SGD with increase in pumping along with the assumed measures to improve the rainfall recharge. Thus, scenario 2 was carried out with $10 \%$ increase in pumping and implementation of managed aquifer recharge (MAR) (with additional check dams, $1 \mathrm{~m}$ increase in crest level of all the existing check dams, rehabilitation of lakes and ponds, and interlinking of Arani and Korttalaiyar rivers) structures in addition to same annual rainfall recharge as in the scenario. Temporal distribution of SGD along the shoreline from January 2020 to December 2030 is shown in Figure 9a and 9b. Comparing this distribution with the baseline scenario, the fresh SGD rate in the unconfined aquifer increases by around $116 \%$, lower than scenario 1. In the semi-confined aquifer, the recirculated seawater SGD rate decreases by about $91 \%$ compared to the baseline scenario, and it increases by around $260 \%$ compared to scenario 1. This is because of a $10 \%$ increase in groundwater pumping.

Scenario 3

Scenario 2 represents the increase in pumping which may adversely affect the aquifer by seawater intrusion. Appropriate and well-organized management is essential to avoid further ingress of seawater intrusion due to over-extraction and to enhance the groundwater quality. Hence, the effect of decrease in groundwater pumping by $10 \%$ was simulated with the assumed MAR structures to improve the groundwater recharge, and following the same annual rainfall recharge i.e. how much \%. By comparing scenario 3 with the baseline, the rate of fresh SGD

467 rises by an average of about $140 \%$ in the unconfined aquifer and the rate of recirculated seawater SGD reduced by an average of about $24 \%$ in the semi-confined aquifer. Comparing 
scenario 3 with scenario 2 indicates greater positive impacts in fresh SGD in the unconfined aquifer and reduction of about $27 \%$ of recirculated seawater SGD towards an inland aquifer. This scenario also follows similar trends of fresh and seawater SGD like scenario 1 and 2. The reduction in groundwater pumping helps to stop seawater intrusion in the semi-confined aquifer and replenish a greater amount of fresh SGD towards the sea in the unconfined aquifer.

\section{Scenario 4}

In order to assess the combined aspect of MAR structures, pumping and rainfall recharge on groundwater head, all these scenarios were combined and the SGD rate was predicted. Scenario 4 was carried out with MAR structures, $10 \%$ increase in rainfall recharge, and termination of pumping from five wellfields. In the unconfined aquifer, the fresh SGD rate has increased at an average of $173 \%$ and $123 \%$ compared to baseline and scenario 3 respectively. Implementation of scenario 4 can help to improve the groundwater quality for a long time. In the semi-confined aquifer, the simulated results show decreasing trend of recirculated seawater SGD i.e. saline water is changed into freshwater (negative values in Fig. 9b) during the monsoon from October to January. Comparing the results of scenario 4 with the baseline show that the rate of seawater SGD is reduced by about $80500 \mathrm{~m}^{3} /$ day during the pre-monsoon i.e. June and about $83200 \mathrm{~m}^{3} /$ day during the post-monsoon i.e. Thus, the implementation of MAR structures enhances the fresh SGD rate during non-monsoon months also, increases base flow. MAR structures provide to maintain the greater groundwater head level and helping to improve base flow during low flow periods. Salameh et al. (2019) also reported the MAR structures can improve the influence of climatic changes on the availability of water in arid and semi-arid areas by increasing the stored amounts of groundwater and the effects of a decrease of seawater intrusion. Hence, the integrated MAR structures, increase in rainfall recharge, and reduction in pumping completely pushes back the freshwater - seawater interface towards the sea and solves 
494

495

496

497

498

499

500

501

502

503

504

505

506

507

508

509

510

511

512

513

514

515

516

517

the seawater intrusion problem during monsoon months. The flow budget for all the scenarios during January 2030 and June 2030 are given in Tables 3 and 4 respectively. This table indicates that the fresh SGD rate to the sea increased by the implementation of measures considered in scenario 4. Fresh SGD discharge is widely used as a water resource for drinking, hygiene, agriculture, fishing, tourism, culture, or ship navigation. In Peru, fresh SGD is used for drinking, on Tahiti for bathing, in Greece for irrigation (Moosdorf and Oehler 2017). In order to restore this coastal aquifer and for sustainable management of water resources, it is essential to adopt measures as suggested in scenario 4 .

"Insert Figure $9 a$ and $9 b "$

\section{Conclusion}

Exchange of submarine flow of water between the sea and aquifer were assessed in the AraniKorttalaiyar river basin, north of Chennai, India, by finite element modelling. The rate of movement of seawater to the aquifer has increased from $17,000 \mathrm{~m}^{3} /$ day to $24,500 \mathrm{~m}^{3} /$ day due to the over-exploitation of groundwater from the semi-confined aquifer. The finite element model was used to predict the effect of recharge structures i.e. with additional check dams, 1 $\mathrm{m}$ increase in crest level of all the existing check dams, interlinking of rivers, $10 \%$ increase in rainfall recharge and termination of pumping from five wellfields. By adopting all possible pumping and recharge methods, seawater moving towards fresh water aquifer (rate of 4,408 $\mathrm{m}^{3} /$ day) can be significantly reduced and fresh SGD (rate of $22,414 \mathrm{~m}^{3} /$ day) rate increased. Thus, the three-dimensional numerical model was successfully used as a tool to quantify the impact of over-exploitation on fresh SGD rates under different scenarios. The insights from this study will be useful for fresh water and saline water management in the coastal areas. 
520

521

522

523

524

525

526

527

528

529

530

531

532

533

534

535

536

537

538

539

540

541

542

543

544

545

546

547

548

549

550

551

\section{Declaration}

Ethics approval and consent to participate - NO

Consent for publication - NO

Availability of data and materials - The groundwater level, rainfall and pumping datasets generated and/or analyzed during the current study are collected from PWD, CGWB and Metro water department

Competing interests - The authors declare that they have no competing interests

Funding - Funding from the Department of Science and Technology, New Delhi, India (Grant number: DST/WAR-W/SWI/05/2010). Co-funding from the European Commission within the Seventh Framework Programme (Grant number: 282911)

Authors' contributions - SPR conceptualized and developed the numerical groundwater flow model and interpreted results. ISN collected data of groundwater level. KB interpreted results of groundwater head. LE conceptualized the idea of this study. All authors were involved in writing and approval of the final manuscript.

Acknowledgements - Funding from the Department of Science and Technology, New Delhi, India (Grant number: DST/WAR-W/SWI/05/2010) is acknowledged. Co-funding for the collaborative project 'Enhancement of natural water systems and treatment methods for safe and sustainable water supply in India - SaphPani' (www.saphpani.eu) from the European Commission within the Seventh Framework Programme (Grant number: 282911) is gratefully acknowledged. The authors thank the Tamil Nadu Public Works Department and the Chennai Metropolitan Water Supply and Sewerage Board, India, for providing the necessary groundwater level and borehole data. Authors greatly acknowledge DHI WASY for providing FEFLOW license. 


\section{References}

Anuthaman NG (2009) Groundwater augmentation by flood mitigation in Chennai region, a modelling based study. Ph.D. thesis. Anna University Chennai, India

Babu DSS, Anish M, Vivekanandan KL, Ramanujam N, Murugan KN, Ravindran AA (2009) An Account of Submarine Groundwater Discharge from the SW Indian Coastal Zone. Journal of Coastal Research 25(1): 91- 104

Basu AR, Jacobsen SB, Poreda RJ, Dowling CB, Aggarwal PK (2001) Large groundwater strontium flux to the oceans from the Bengal Basin and the marine strontium isotope record. Science 293: 1470-1473

Biswas H, Sena DR, Kumar G, Lakaria BL, Raizada A, Kumar S, Mishra PK (2017) Effect of water storage structures on groundwater recharge in India. Groundwater for Sustainable Development 4: 49-56

Bobba AG (2011) Simulation of Groundwater and Contamination Discharge from Krishna Godavari Coast to Bay of Bengal, India

Bokuniewicz H, Buddemeier R, Maxwell B, Smith C (2003) The typological approach to submarine ground-water discharge (SGD). Biogeochemistry 66: 145-158

CGWB 2007, District ground water brochure Tiruvallur district

Chakrabarti R, Mondal S, Acharya SS, Lekha JS, Sengupta D (2018) Submarine groundwater discharge derived strontium from the Bengal Basin traced in Bay of Bengal water samples. Nature. Scientific Reports 8: 4383

Charalambous AN, Garratt P (2009) Recharge-abstraction relationships and sustainable yield in the Arani-Kortalaiyar groundwater basin, India. Quarterly Journal of Engineering Geology and Hydrogeology 42: 39-50

Chidambaram S, Nepolian M, Ramanathan AL et al (2017) An attempt to identify and estimate the subsurface groundwater discharge in the south-east coast of India. International Journal 
of Sustainable Built Environment 6: 421-433

579

580

581

582

583

584

585

586

587

588

589

590

591

592

593

594

595

596

597

598

599

600

601

602

Custodio, E. (2002) Aquifer Overexploitation: What Does It Mean? Hydrogeol. J. 10: 254-277

Debnath P, Das K, Mukherjee A, Ghosh NC, Rao S, Kumar S, Krishan G, Joshi G (2019) Seasonal-to-diurnal scale isotopic signatures of tidally-influenced submarine groundwater discharge to the Bay of Bengal: Control of hydrological cycle on tropical oceans. Journal of Hydrology 571: 697-710

Debnath P, Mukherjee A (2016) Quantification of tidally-influenced seasonal groundwater discharge to the Bay of Bengal by seepage meter study. Journal of Hydrology 537: 106 116

Debnath P, Mukherjee A, Das K (2018) Characterization of tidally-influenced seasonal nutrient flux to the Bay of Bengal and its implications on the coastal ecosystem. Hydrological Processes. DOI: 10.1002/hyp.11507

Debnath P, Mukherjee A, Singh HK, Mondal S (2015) Delineating seasonal porewater displacement on a tidal flat in the Bay of Bengal by thermal signature: Implications for submarine groundwater discharge. Journal of Hydrology 529: 1185-1197

DHI (2009b) Finite element subsurface flow and transport simulation. White paper vol.

Fetter CW (2001) Applied Hydrogeology. 4th Edition, Prentice - Hall in, Upper Saddle river, NJ

Finkl CW, Krupa SL (2003) Environmental impacts of coastal-plain activities on sandy beach systems: hazards, perception and mitigation. J. Coastal Res. 35: 132-150

GEC (1997) Groundwater Resource Estimation Methodology. Report of the Groundwater Resource Estimation Committee, Ministry of Water Resources, Government of India

George ME, Babu DSS, Akhil T, Rafeeque MK (2018) Investigation on Submarine Groundwater Discharge at Kozhikkode Coastal Aquifer, SW Western Ghats. Journal Geological Society of India 92: 626-633 
603

604

605

606

607

608

609

610

611

612

613

614

615

616

617

618

619

620

621

622

623

624

625

626

627

Gowrisankar G, Chelliah R, Ramakrishnan SR, Elumalai V, Dhanamadhavan S, Brindha K, Antony U, Elango L (2017) Chemical, microbial and antibiotic susceptibility analyses of groundwater after a major flood event in Chennai. Sci Data. 4: 170135

Grove DB (1976) Ion exchange reactions important in groundwater quality model. Advances in Groundwater Hydrology 409-436

INCCA (2010) Climate change and India: A 4x4 assessment a sectoral and regional analysis for 2030's

Jacob N, Babu DSS, Shivanna K (2009) Radon as an indicator of submarine groundwater discharge in coastal regions. Current Science 97(9): 1313-1320

Konikow LF (1996) Numerical models of groundwater flow and transport. In: Manual on Mathematical Models in Isotope Hydrogeology. International Atomic Energy Agency Report: 59-112

Kourakos G, Dahlke HE, Harter T (2019). Increasing groundwater availability and seasonal base flow through agricultural managed aquifer recharge in an irrigated basin. Water Resources Research 55: 7464-7492

Krishan G, Rao MS, Kumar CP, Kumar S, Rao MRA (2015) A study on identification of submarine groundwater discharge in northern east coast of India. Aquatic Procedia 4: 3 10

Kwon EY, Kim G, Primeau F, Moore WS, Cho HM, DeVries T, Sarmiento JL, Charette MA, and Cho YK (2014) Global estimate of submarine groundwater discharge based on an observationally constrained radium isotope model. AGU, Geophysical Research Letters 10.1002/2014GL061574

Langevin CD (2003) Simulation of submarine groundwater discharge to a marine estuary: Biscayne Bay, Florida. Ground Water 41(6): 758-771

Luijendijk E, Gleeson T, Moosdorf N (2020) Fresh groundwater discharge insignificant for the 
world's oceans but important for coastal ecosystems. Nature Commun. 11: 1260

Manivannan V, Elango L (2019) Seawater intrusion and submarine groundwater discharge along the Indian coast. Environmental Science and Pollution Research. https://doi.org/10.1007/s11356-019-06103-z

Meijer P (2012) Case study on extraction of groundwater in the A-K basin in the north of Chennai, India. Master Thesis. Wageningen University

Moosdorf, Oehler (2017). Societal use of fresh submarine groundwater discharge: An overlooked water resource. Earth-Science Reviews 171: 338-348

Pathak S (2019) No Drips, No Drops: A City Of 10 Million Is Running Out Of Water

Prakash R, Srinivasamoorthy K, Gopinath S, Saravanan K (2018) Measurement of submarine groundwater discharge using diverse methods in Coleroon Estuary, Tamil Nadu, India. Applied Water Science 8: 13

Rahaman W, Singh SK (2012) Sr and ${ }^{87} \mathrm{Sr} /{ }^{86} \mathrm{Sr}$ in estuaries of western India: Impact of submarine groundwater discharge. Geochimica et Cosmochimica Acta 85: 275-288

Rajaveni SP (2015) Integrated approach of modelling of runoff, infiltration and density dependent groundwater flow: A case study in seawater intruded coastal aquifer north of Chennai, India. Ph.D. thesis, Anna University Chennai, India

Rajaveni SP, Indu SN, Elango L (2016) Finite element modelling of a heavily exploited coastal aquifer for assessing the response of groundwater level to the changes in pumping and rainfall variation due to climate change. Hydrology Research 47(1): 42-60

Rao SVN, Saheb SM, Ramasastri KS (2004b) Aquifer restoration from seawater intrusion: a preliminary field scale study of the Minjur aquifer system, north of Chennai, Tamil Nadu, India, Proceedings of 18th Seawater Intrusion Meeting Cartagena, Spain: 707 - 715

Ravindran AA, Ramanujam N (2014) Detection of submarine groundwater discharge to coastal zone study using 2D electrical resistivity imaging study at Manapad, Tuticorin, India. 
653

654

655

656

657

658

659

660

661

662

663

664

665

666

667

668

669

670

671

672

673

674

675

676

677

Indian Journal of Geo-Marine Sciences 43(2): 224-228

Rengarajan R, Sarma VVSS (2015) Submarine groundwater discharge and nutrient addition to the coastal zone of the Godavari estuary. Marine Chemistry 172: 57-69

Rushton KR (2003) Groundwater Hydrology: Conceptual and Computational Models. Wiley Published 430

Salameh E, Abdallat G, Valk MVD (2019) Planning Considerations of Managed Aquifer Recharge (MAR) Projects in Jordan. Water 11: 182

Srinivasamoorthy K, Ponnumani G, Prakash R, Gopinath S, Saravanan K, Vinnarasi F (2018) Tracing groundwater inputs to Bay of Bengal from Sankarabarani River Basin, Pondicherry, India, using continuous radon monitoring. Int J Environ Sci Technol

Taniguchi M, Burnett WC, Cable JE, Jeffrey V, Turner (2002) Investigation of submarine groundwater discharge. Hydrol. Process 16: 2115-2129

Taniguchi M, Dulai H, Burnett KM, Santos IR, Sugimoto R, Stieglitz T, Kim G, Moosdorf N, Burnett WC (2019) Submarine Groundwater Discharge: Updates on Its Measurement Techniques, Geophysical Drivers, Magnitudes, and Effects, Frontiers in Environmental science $7: 141$

TNPWD (2012). Thiruvallur district report, Government of Tamil Nadu

Todd DK (2001) Groundwater Hydrology. 2nd Edition, John wiley \& Sons, New York

UNDP (1987) Hydrogeological and artificial recharge studies Madras, Technical report, United Nations Department of technical co-operation for development, New York, USA

Vollberg F, Walther M, Gärdes A, Moosdor N (2019) Modeling the Potential of Submarine Groundwater Discharge to Facilitate Growth of Vibrio cholerae Bacteria. Hydrology 6: 39

Virtasalo JJ, Schröder JF, Luoma S, Majaniemi J, Mursu J, Scholten J (2019) Submarine groundwater discharge site in the First Salpausselkä ice-marginal formation, south Finland. Solid Earth 10: 405-423 
678 Welch E M, Dulai H, El-Kadi A, Shuler C K (2019) Submarine Groundwater Discharge and 679 Stream Baseflow Sustain Pesticide and Nutrient Fluxes in Faga'alu Bay, American Samoa. $680 \quad$ Front. Environ

681 Yadav VB, Jha SK, Pulhani V, Tripathi RM (2019) Estimation of submarine groundwater 682 discharge using radium mass-balance in Mumbai Harbour Bay, Mumbai, India. J 683 Radioanal Nucl Chem. 319(3): 945-952

684

685

686

687

688

689

690

691

692

693

694

695

696

697

698

699

700

701

702 
703

$704 \quad$ List of Tables

705 Table 1 SGD studies carried out along the coast of India

706 Table 2 Aquifer parameters used in the model

707 Table 3 Rate of SGD for all the scenarios during January 2030

708 Table 4 Rate of SGD for all the scenarios during June 2030

709

710

711

712

713

714

715

716

717

718

719

720

721

722

723

724

725

726

727 


\section{List of Figures}

730

731

732

733

734

735

736

737

738

739

740

741

742

743

744

745

746

747

748

749

750

751

752

Fig. 1 Location of the study area

Fig. 2 (a) Geology of the study area (b) West to east geological cross section along A-A'

Fig. 3 (a) Perspective view of the three-dimensional discretization of the aquifer system (b) North south cross section

Fig. 4 Monthly variations in rainfall and groundwater head in the unconfined aquifer

Fig. 5 Comparison between the observed and simulated groundwater heads after the steady state calibration (a) Unconfined aquifer (b) Semi confined aquifer \& after transient state calibration (c) Unconfined aquifer (d) Semi confined aquifer

Fig. 6 Simulated groundwater head showing in the aquifer cross-section (a) January and (b) June for the years 2000, 2005 and 2010

Fig. 7 Temporal variations of total SGD along the eastern boundary in the (a) unconfined aquifer (b) semi confined aquifer

Fig. 8 Total groundwater flux along the eastern boundary (a) for a month of January 2000, 2005 and 2010 (b) June 2000, 2005 and 2010

Fig. 9 Predicted rate of SGD along the eastern boundary in the (a) unconfined aquifer (b) semi confined aquifer

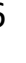

.

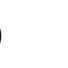

.


Table 1 SGD studies carried out along the Indian coast

\begin{tabular}{|c|c|c|c|}
\hline Location & Method & SGD & Reference \\
\hline Bengal basin & ${ }^{87} \mathrm{~S}_{\mathrm{r}} /{ }^{86} \mathrm{~S}_{\mathrm{r}}$ ratio & $0.2 \times 10^{15}$ litre/year & Basu et al. (2001) \\
\hline Vizhinjam, Kerala & Groundwater modelling & $10.9 \pm 6.1 \mathrm{~cm} /$ day & Babu et al. (2009) \\
\hline Vizhinjam, Kerala & Radium and radon isotopes & $10.9 \pm 6.1 \mathrm{~cm} /$ day & Jacob et al. (2009) \\
\hline $\begin{array}{l}\text { Krishna-Godavari } \\
\text { Coast }\end{array}$ & $\begin{array}{l}\text { Dupuit Ghyben Herzberg model and } \\
\text { Darcy's law }\end{array}$ & $0.752 \mathrm{~m}^{3} /$ day & Bobba (2011) \\
\hline Narmada estuary & $\begin{array}{l}\text { The inverse model used to identify } \mathrm{S}_{\mathrm{r}} \\
\text { concentration, the }{ }^{87} \mathrm{~S}_{\mathrm{r}} /{ }^{66} \mathrm{~S}_{\mathrm{r}} \text { ratio }\end{array}$ & $\begin{array}{l}5 \mathrm{~cm} / \text { day during pre- } \\
\text { monsoon } 280 \mathrm{~cm} / \text { day during } \\
\text { monsoon }\end{array}$ & Rahaman and Singh (2012) \\
\hline Manapad, Tuticorin & $\begin{array}{l}\text { 2D electrical resistivity imaging and } \\
\text { Darcy law }\end{array}$ & $\begin{array}{l}0.020 \mathrm{~m}^{3} / \text { day, } 0.006 \mathrm{~m}^{3} / \text { day } \\
\text { and } 0.091 \mathrm{~m}^{3} / \text { day }\end{array}$ & $\begin{array}{l}\text { Ravindran and Ramanujam } \\
\text { (2014) }\end{array}$ \\
\hline Chandipur & Temperature and chemical profiling & $1.16 \times 10^{7} \mathrm{~m}^{3} / \mathrm{y}$ & Debnath et al. (2015) \\
\hline Godavari estuary & $\begin{array}{l}\text { 1.Three end-member mixing model } \\
\text { 2.Radium mass balance approach }\end{array}$ & $\begin{array}{l}6.8 \text { to } 12.7 \times 10^{6} \mathrm{~m}^{3} / \mathrm{d} \\
1.55 \text { to } 7.44 \times 10^{6} \mathrm{~m}^{3} / \mathrm{d} \text { and } \\
1.34 \text { to } 5.60 \times 10^{6} \mathrm{~m}^{3} / \mathrm{d}\end{array}$ & $\begin{array}{l}\text { Rengarajan and Sarma } \\
(2015)\end{array}$ \\
\hline Bengal basin & $\begin{array}{l}{ }^{222} \mathrm{Rn} \text { measurement of groundwater } \\
\text { sample }\end{array}$ & $\begin{array}{l}\text { Identified SGD location } \\
\text { through }{ }^{222} \mathrm{Rn}\end{array}$ & Krishan et al. (2015) \\
\hline Chandipur & Seepage meter and Cluster experiment & $8.98 \pm 0.6 \times 10^{8} \mathrm{~m}^{3} / \mathrm{y}$ & $\begin{array}{l}\text { Debnath and Mukherjee } \\
\text { (2016) }\end{array}$ \\
\hline Cuddalore region & Radon, EC concentration and tide & $37.24-79.16 \mathrm{~cm} /$ day & Chidambaram et al. (2017) \\
\hline $\begin{array}{l}\text { Basin to the Bay of } \\
\text { Bengal }\end{array}$ & Calculating strontium $\left(\mathrm{S}_{\mathrm{r}}\right)$ flux & Identified SGD locations & Chakrabarti et al. (2018) \\
\hline $\begin{array}{l}\text { Coleroon estuary } \\
\text { (Tributary of Cauvery } \\
\text { river) }\end{array}$ & $\begin{array}{l}\text { 1.Water budget, } \\
\text { 2.Darcy law } \\
\text { 3.Manual seepage meter }\end{array}$ & $\begin{array}{l}6.9 \times 10^{6} \text { and } 3.2 \times 10^{3} \\
\mathrm{~m}^{3} / \mathrm{yr} \text { to } 308.3 \times 10^{3} \mathrm{~m}^{3} / \mathrm{yr}\end{array}$ & Prakash et al. (2018) \\
\hline Kozhikkode coast & $\begin{array}{l}\text { 1.Water table elevation surveys } \\
\text { 2. in situ hydrochemical } \\
\text { 3. Resistivity surveys }\end{array}$ & $\begin{array}{l}\text { Flow path of the } \\
\text { groundwater discharge is } \\
\text { located }\end{array}$ & George et al. (2018) \\
\hline $\begin{array}{l}\text { Sankarabarani river } \\
\text { basin }\end{array}$ & Radon mass balance model & $0.88 \mathrm{~m} /$ day & $\begin{array}{l}\text { Srinivasamoorthy et al. } \\
\text { (2018) }\end{array}$ \\
\hline Chandipur & $\begin{array}{l}\text { Stable isotopic and } \\
\text { chemical studies }\end{array}$ & $\begin{array}{l}\text { High-resolution, temporally- } \\
\text { variable, stable isotope } \\
\text { patterns of SGD is studied }\end{array}$ & Debnath et al. (2019) \\
\hline Mumbai Harbour Bay & $\begin{array}{l}\text { Ra isotopes ( } \mathrm{Ra} \text { and } \mathrm{Ra} \text { ) mass balance } \\
\text { method }\end{array}$ & $\begin{array}{l}33.4 \times 10^{9} \text { lit/day and } 64.9 \times \\
10^{9} \text { lit/ day }\end{array}$ & Yadav et al. (2019) \\
\hline Indian coast & Analysis of groundwater level & Identified the location & $\begin{array}{l}\text { Manivannan and Elango } \\
\text { (2019) }\end{array}$ \\
\hline
\end{tabular}




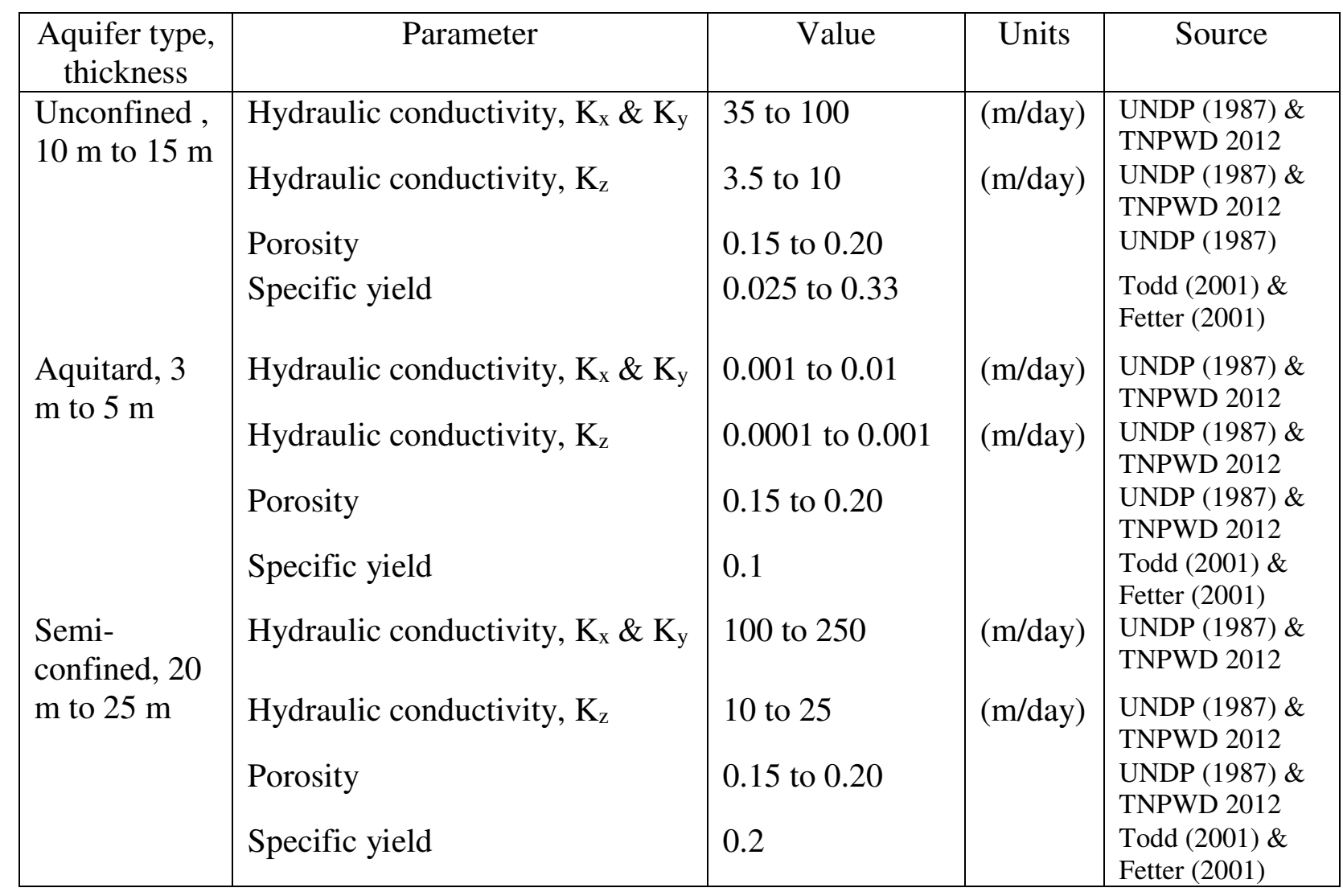


Table 3 Rate of SGD for all the scenarios during January $2030\left(\mathrm{~m}^{3}\right)$

\begin{tabular}{|c|c|c|c|c|c|c|c|}
\hline \multirow{2}{*}{$\begin{array}{l}\text { S. } \\
\text { No. }\end{array}$} & \multirow[b]{2}{*}{ Scenario } & \multicolumn{2}{|c|}{ Recharge } & \multicolumn{2}{|c|}{ Abstraction } & \multirow{2}{*}{$\begin{array}{l}\text { Lateral } \\
\text { inflow }\end{array}$} & \multirow{2}{*}{$\begin{array}{l}\text { Lateral } \\
\text { outflow }\end{array}$} \\
\hline & & $\begin{array}{c}\text { River } \\
\text { recharge }\end{array}$ & $\begin{array}{l}\text { Rainfall } \\
\text { recharge }\end{array}$ & Crop & $\begin{array}{l}\text { Well } \\
\text { field }\end{array}$ & & \\
\hline 1 & $\begin{array}{l}\text { Baseline } \\
\text { scenario }\end{array}$ & 1603500 & 262360 & 1377500 & 48011 & 2232220 & 2672569 \\
\hline 2 & Scenario 1 & 1300175 & 288596 & 1377500 & 48011 & 1837515 & 2000775 \\
\hline 3 & Scenario 2 & 1816513 & 262360 & 1515250 & 52812 & 2316015 & 2826826 \\
\hline 4 & Scenario 3 & 1684750 & 262360 & 1239750 & 43210 & 2911830 & 3575980 \\
\hline 5 & Scenario 4 & 1417159 & 288596 & 1377500 & 9035 & 3538664 & 3857884 \\
\hline
\end{tabular}

771

772

773

774

775

776

777

778

779

780

781

782

783 
Table 4 Rate of SGD for all the scenarios during June $2030\left(\mathrm{~m}^{3}\right)$

\begin{tabular}{|c|l|c|c|c|c|c|c|}
\hline \multirow{2}{*}{ S. } & \multirow{2}{*}{ No. } & \multicolumn{2}{|c|}{ Recharge } & \multicolumn{2}{c|}{ Abstraction } & Lateral & Lateral \\
\cline { 3 - 6 } & & River & Rainfall & Crop & Well & inflow & outflow \\
\hline 1 & Baseline & 688240 & 1829700 & 2283500 & 56975 & 2256110 & 2433575 \\
2 & Scenario & & & & & & \\
3 & Scenario 1 & 705702 & 2012670 & 2283500 & 56975 & 1654961 & 2032858 \\
4 & Scenario 2 & 1044162 & 1829700 & 2511850 & 62673 & 1964809 & 2264148 \\
5 & Scenario 3 & 983641 & 1829700 & 2055150 & 51278 & 2426585 & 3133498 \\
\hline
\end{tabular}

787

788

789

790

791

792

793

794

795

796

797

798

799

800 


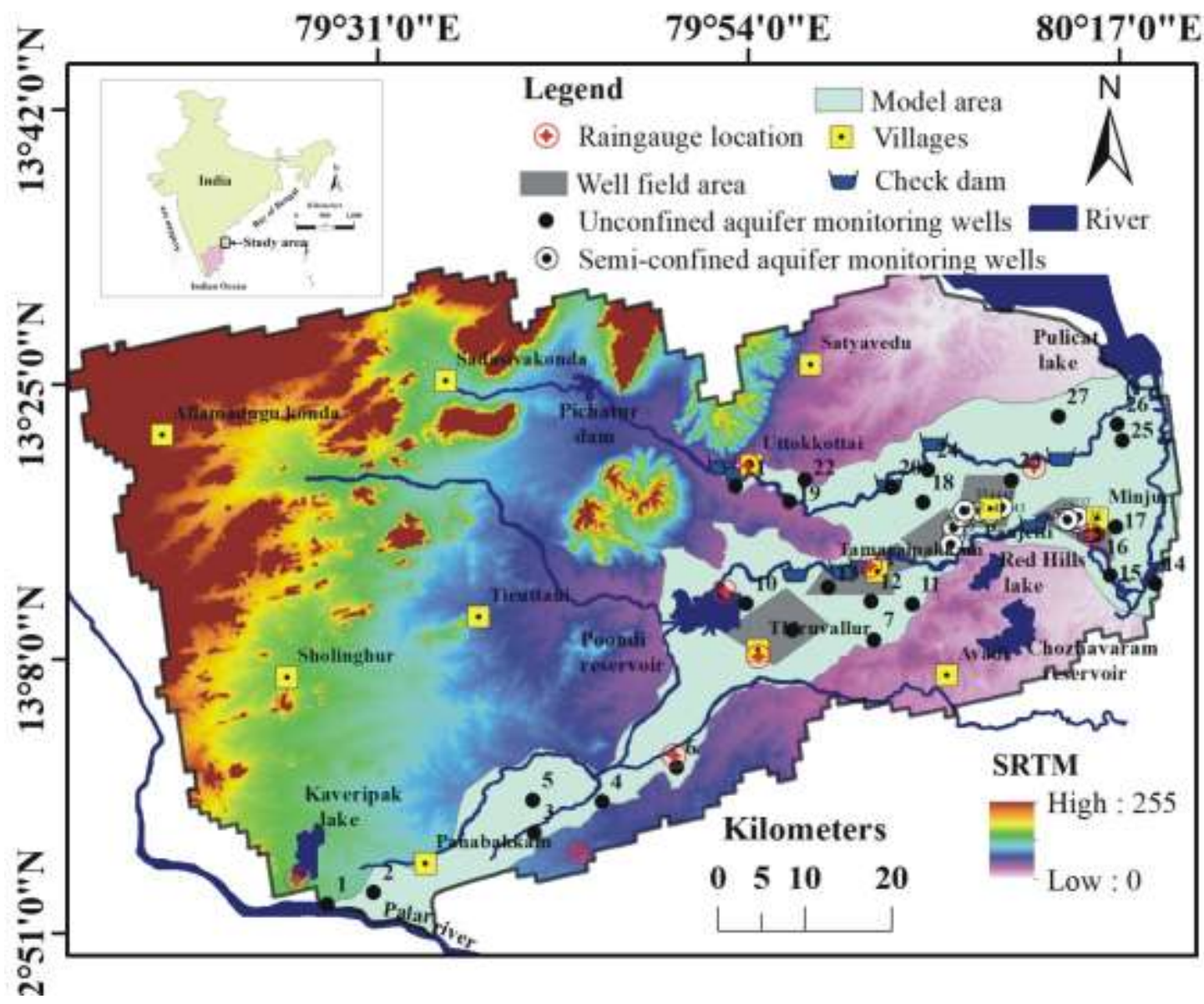

805

Fig. 1 Location of the study area

806 

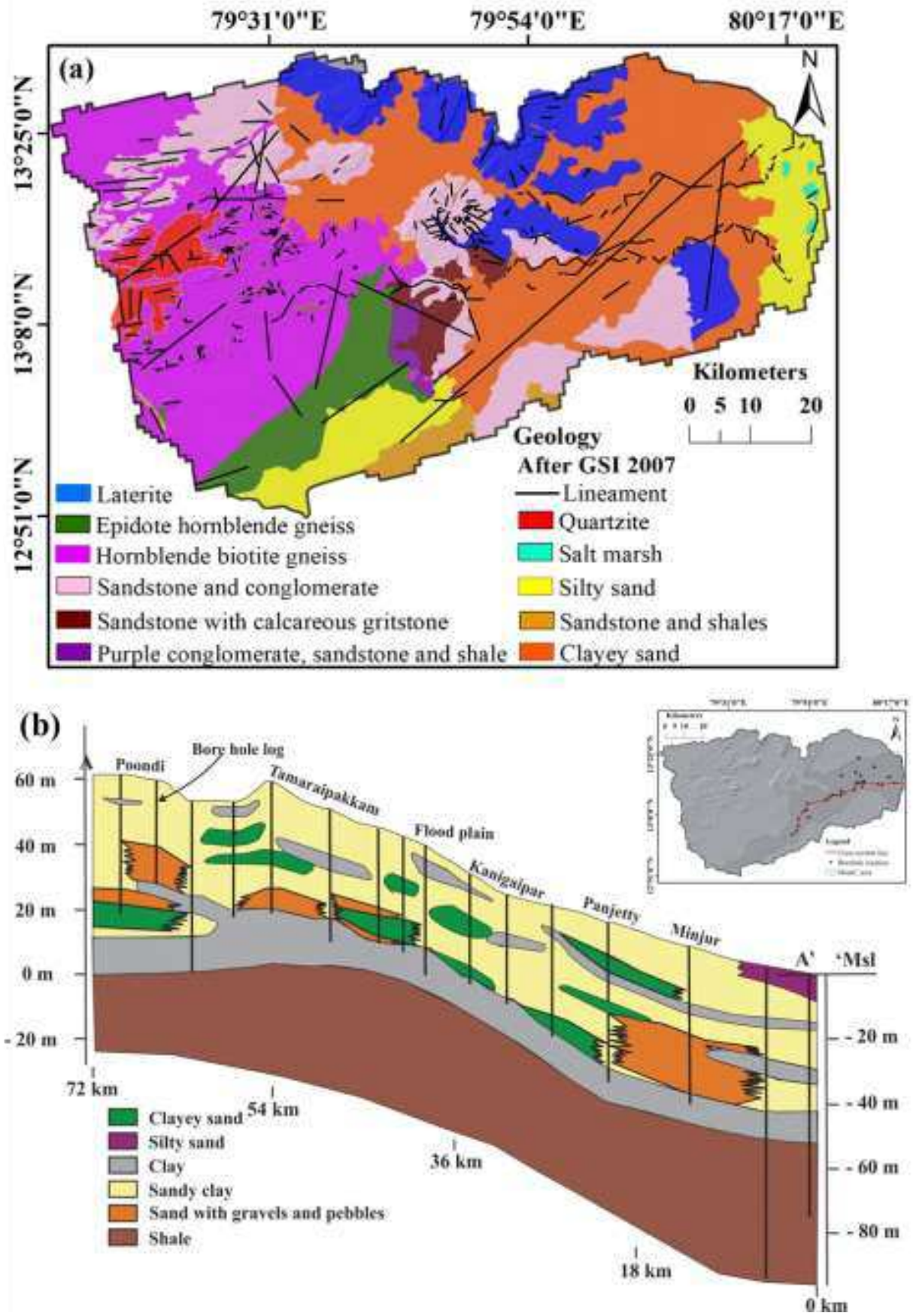

818 Fig. 2 (a) Geology of the study area (b) West to east geological cross section along A-A' 

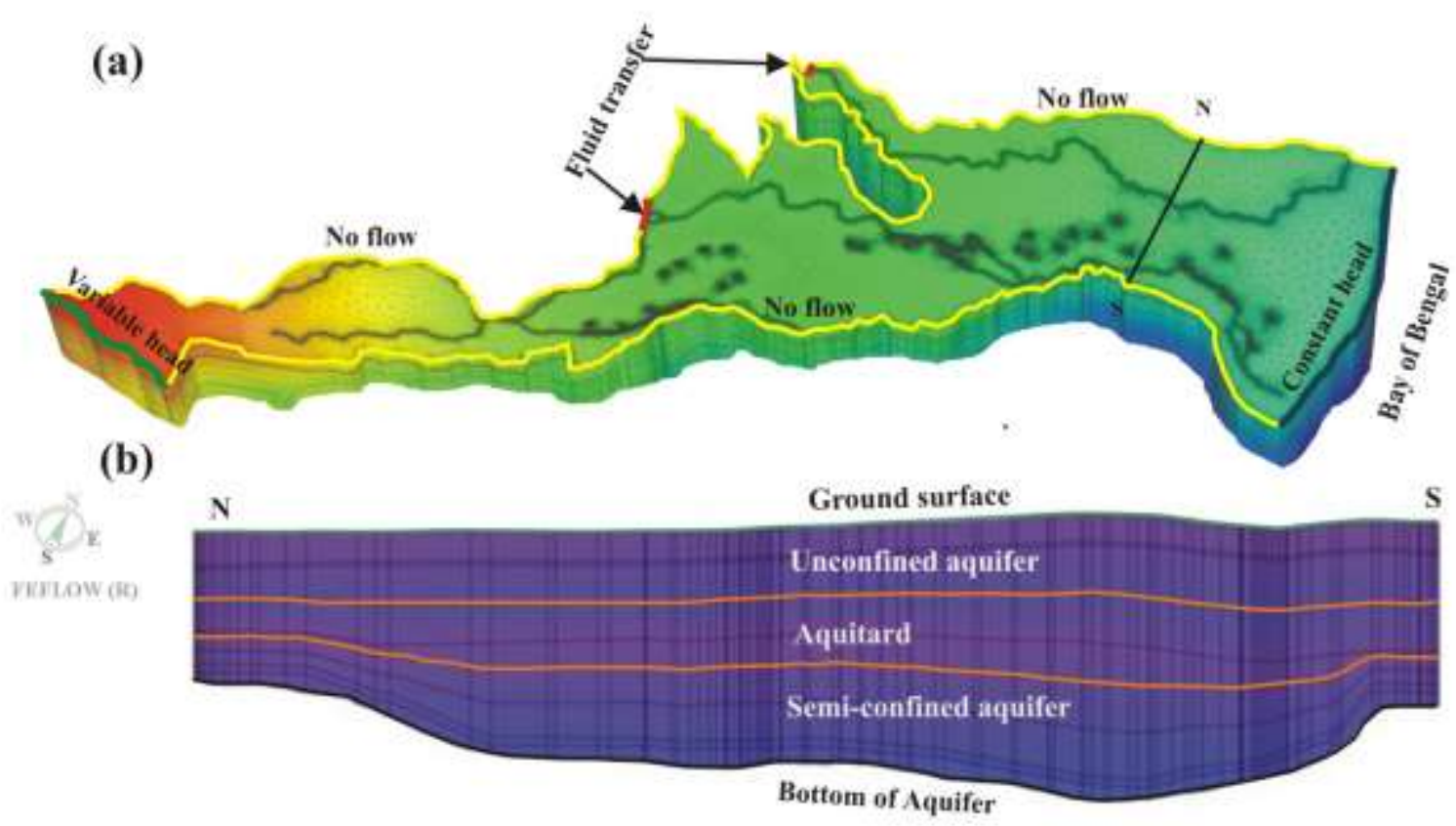

824

825 Fig. 3 (a) Perspective view of the three-dimensional discretization of the aquifer system (b) North south cross section

827 

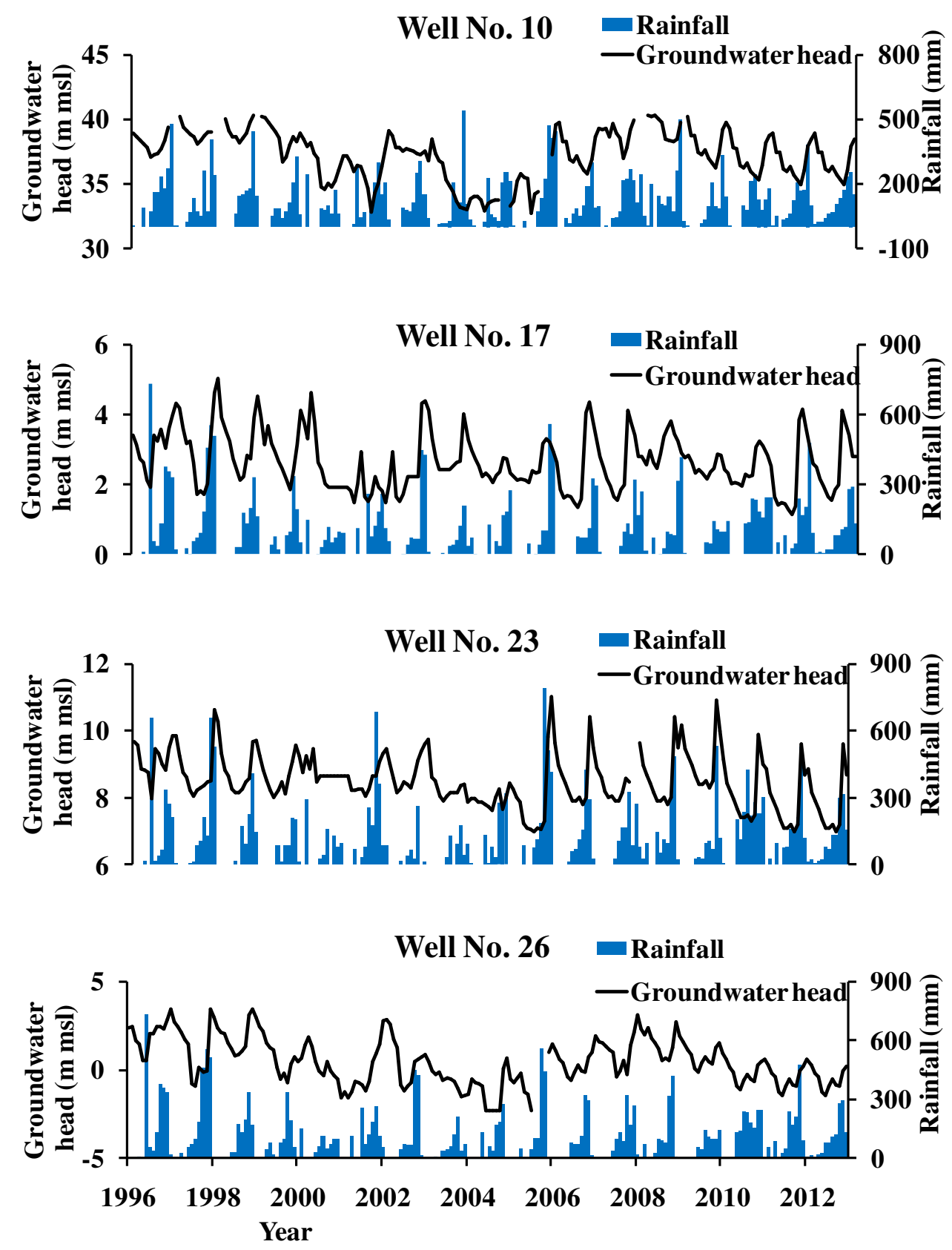

Fig. 4 Monthly variations in rainfall and groundwater head in the unconfined aquifer 

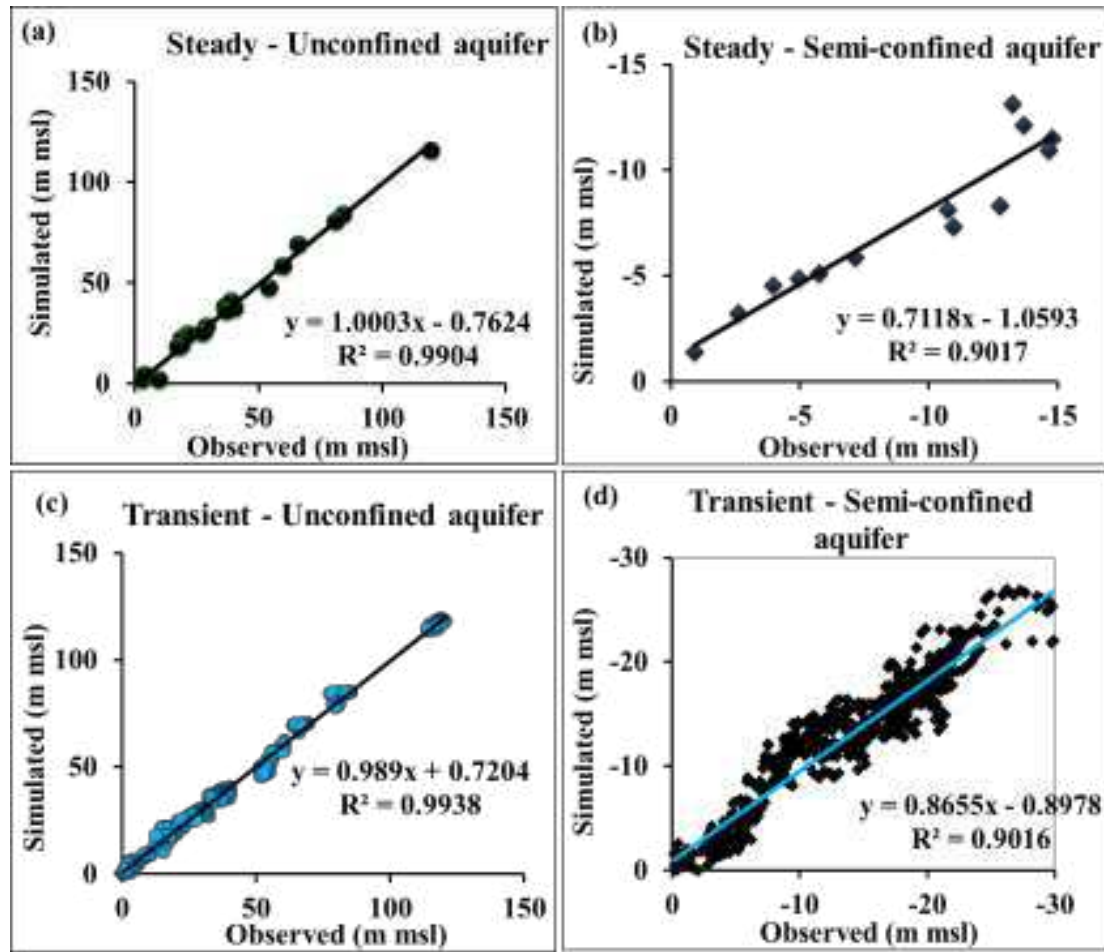

851

Fig. 5 Observed and simulated groundwater heads in steady state (a) unconfined aquifer 


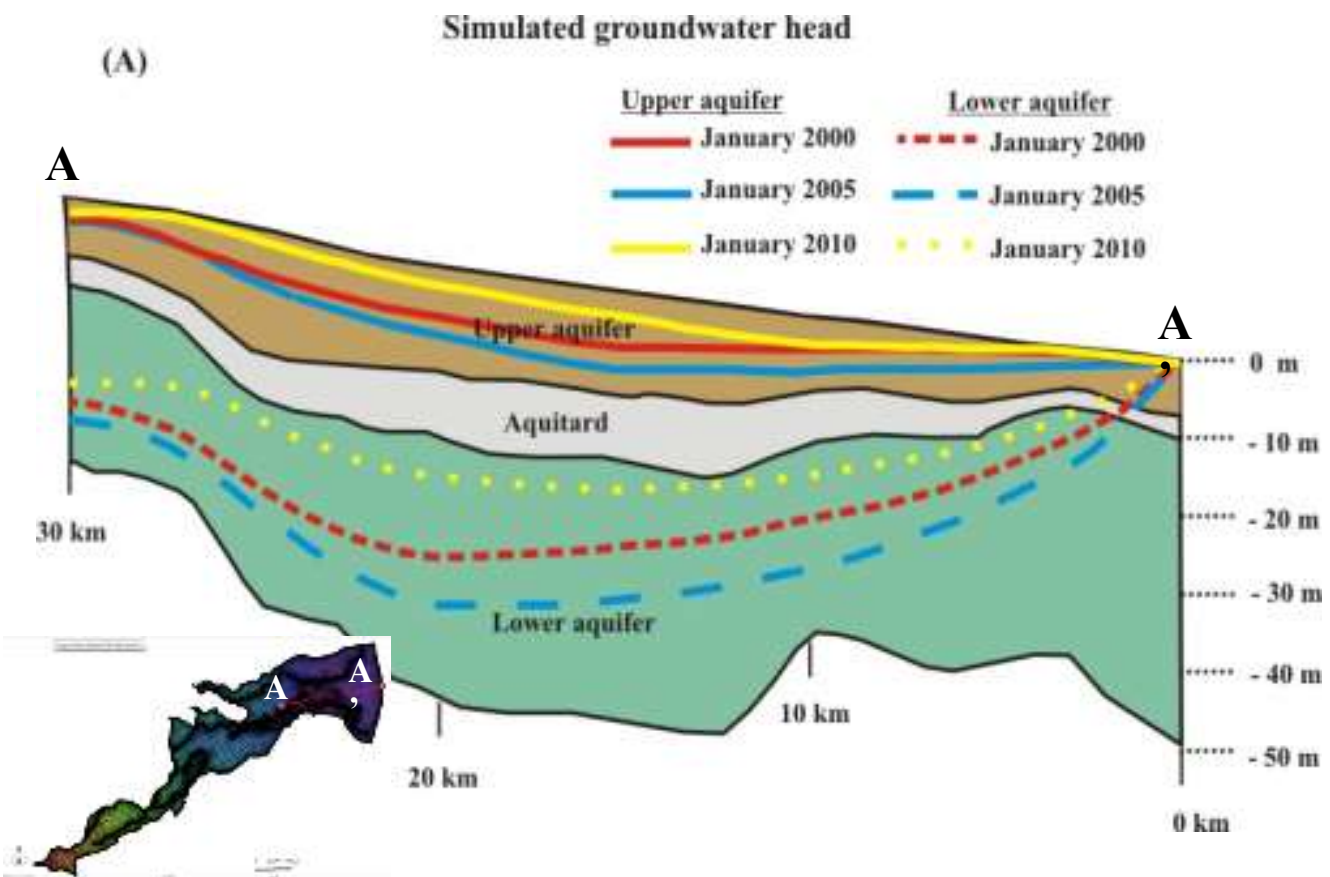

(B)

Simulated groundwater head

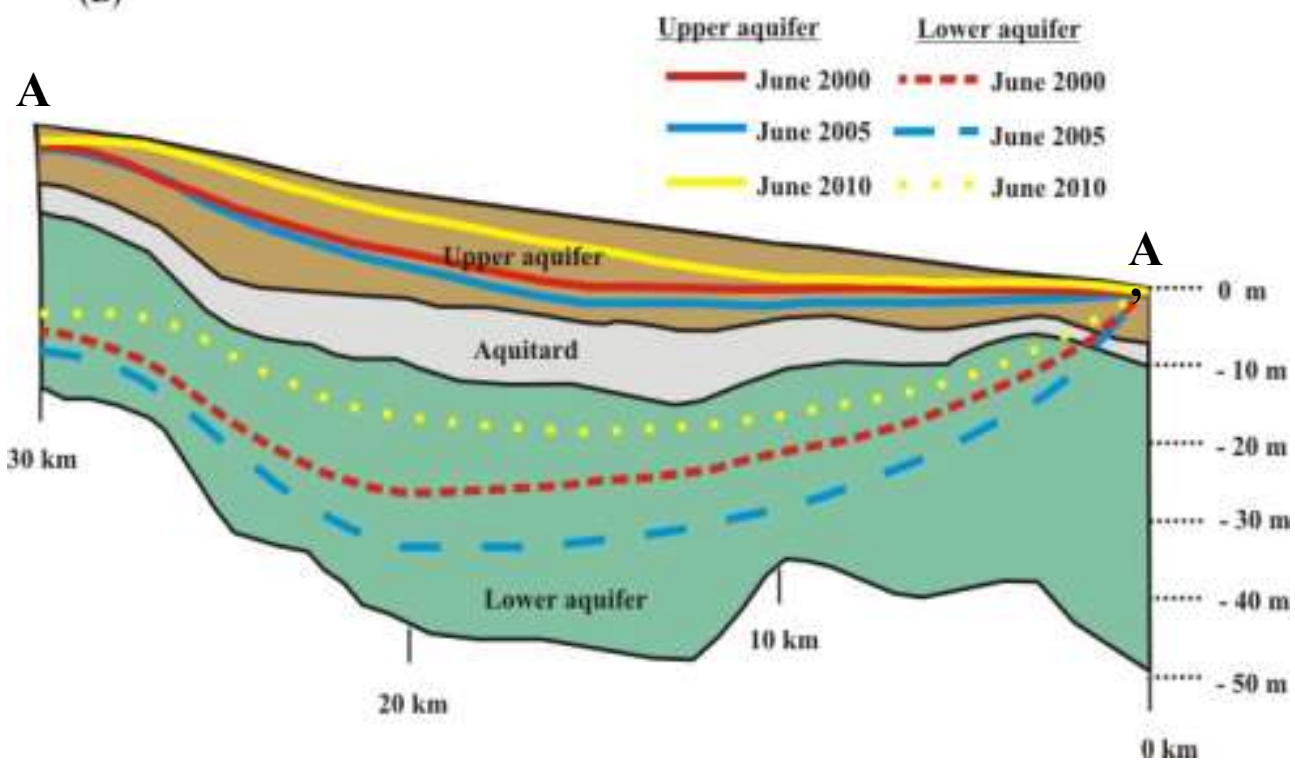

868 Fig. 6 Simulated groundwater head showing in the aquifer cross-section (a) January and

(b) June for the years 2000, 2005 and 2010 
872

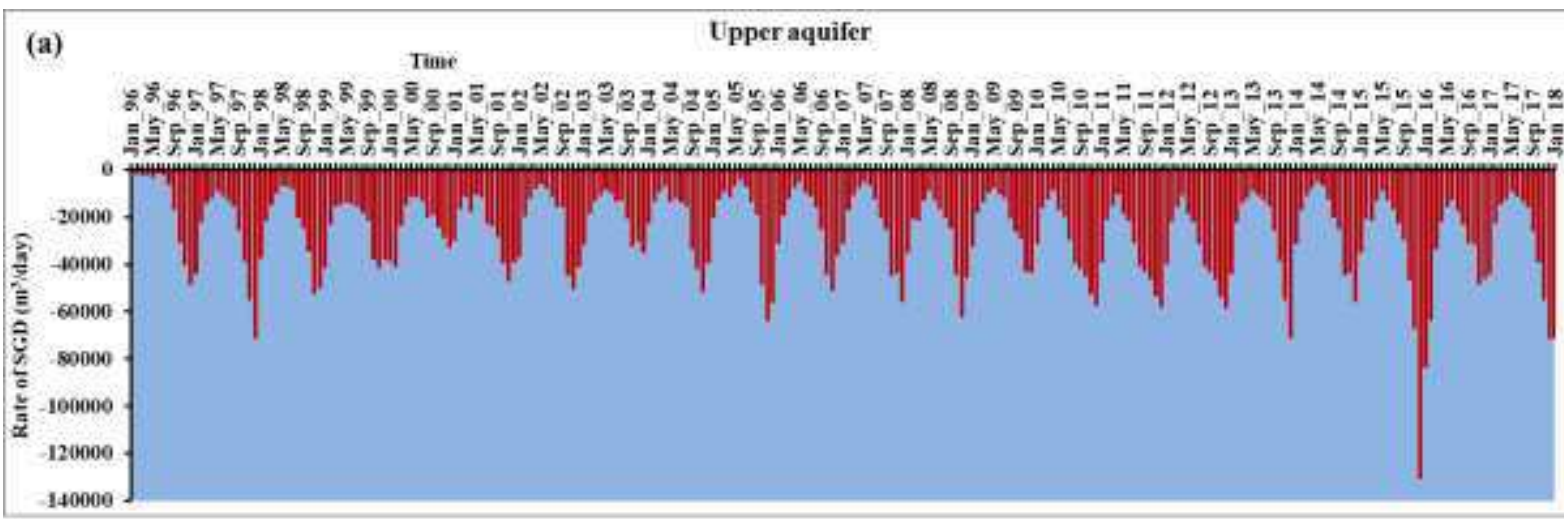

(b)

Lower aquifer

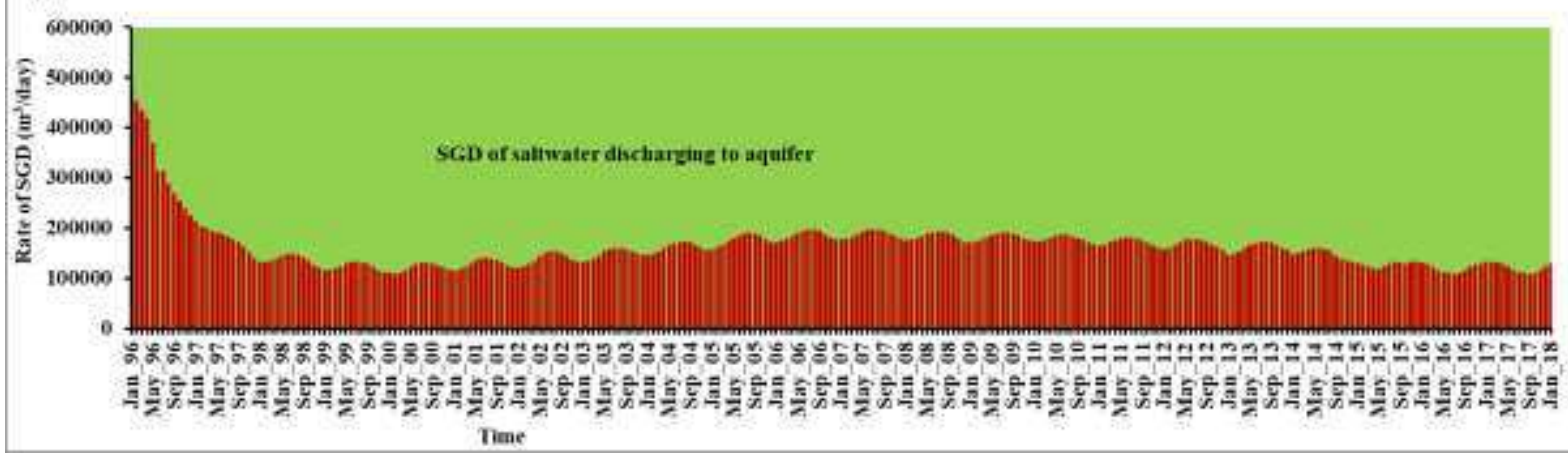

Fig. 7 Temporal variations of total SGD along the eastern boundary (a) unconfined 

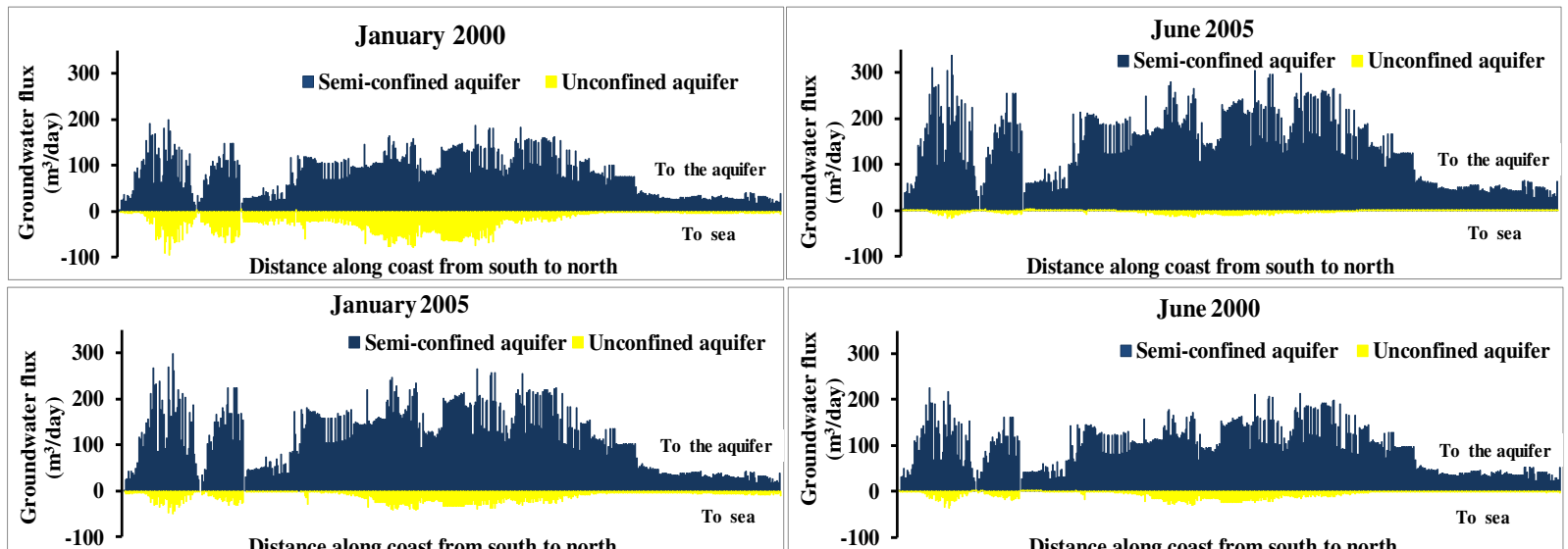

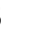
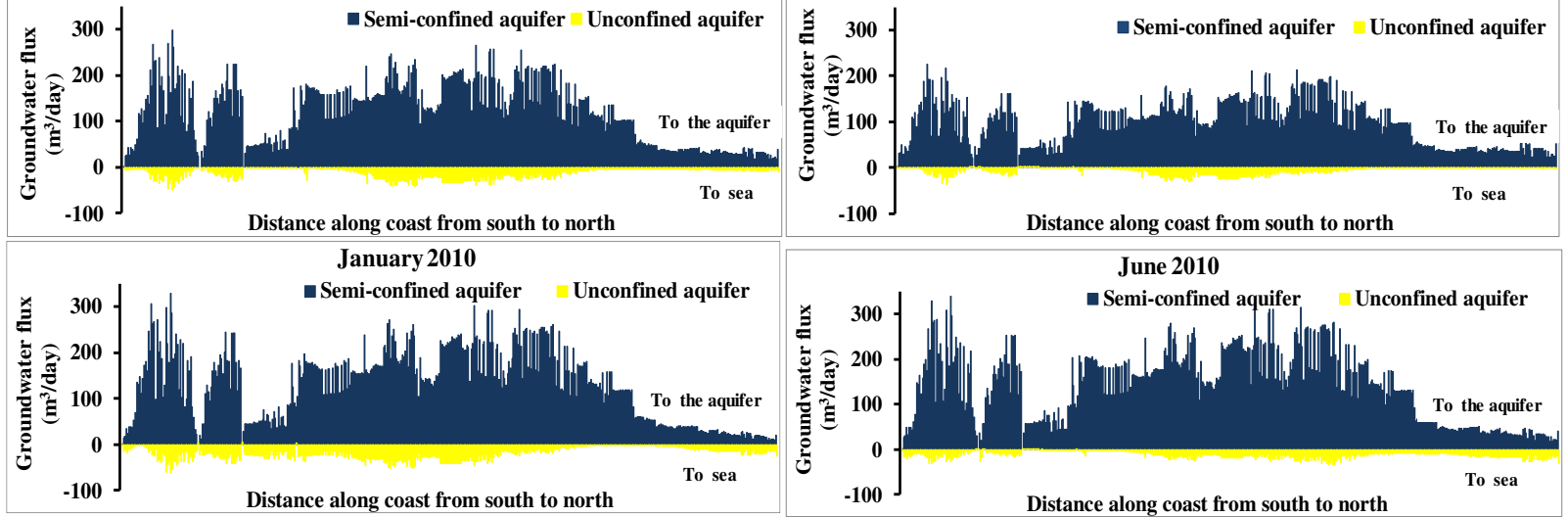

Fig. 8 Total groundwater flux along the eastern boundary (a) January 2000, 2005 and 

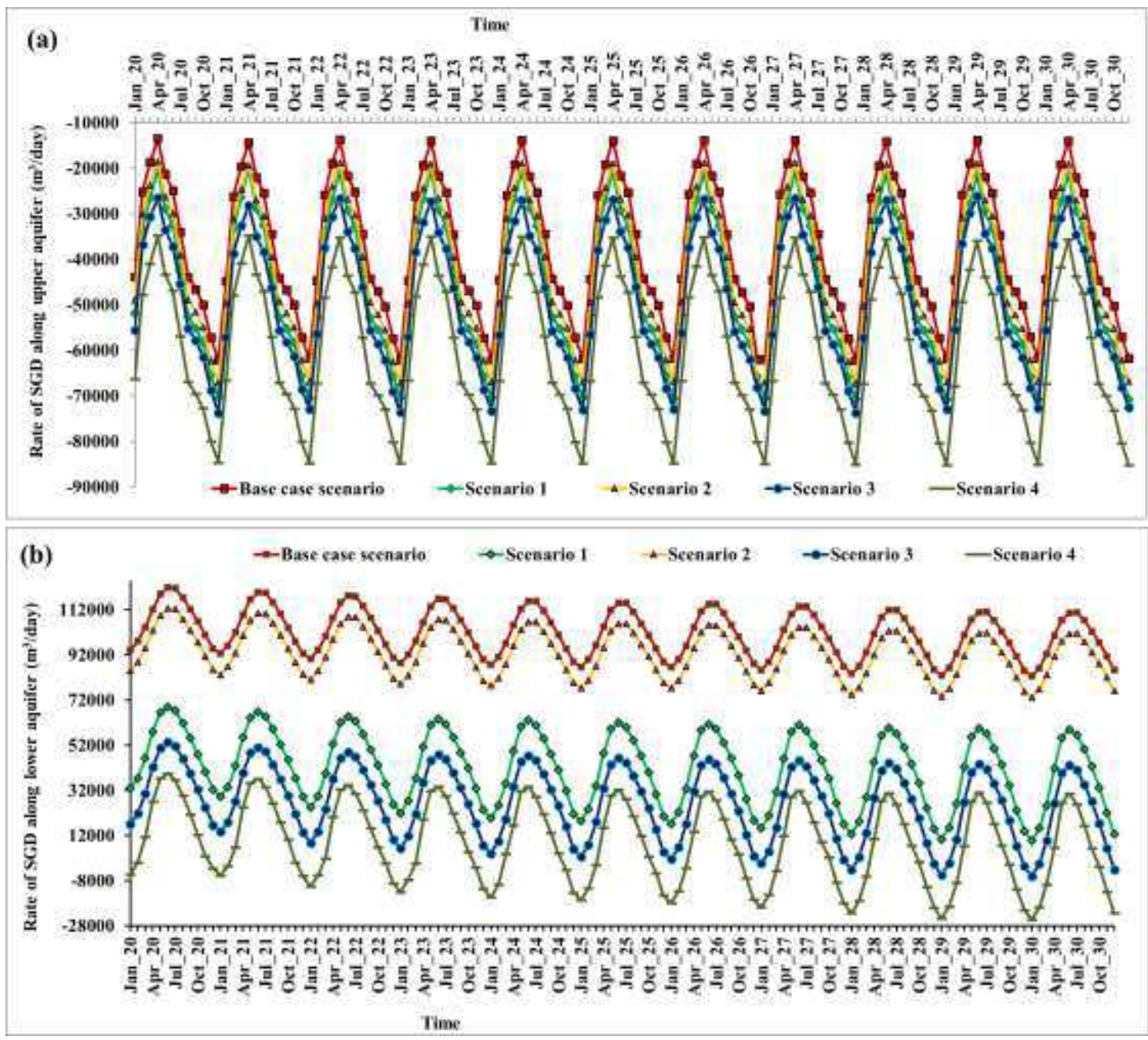

Fig. 9 Predicted rate of SGD along the eastern boundary in the (a) unconfined aquifer (b) 


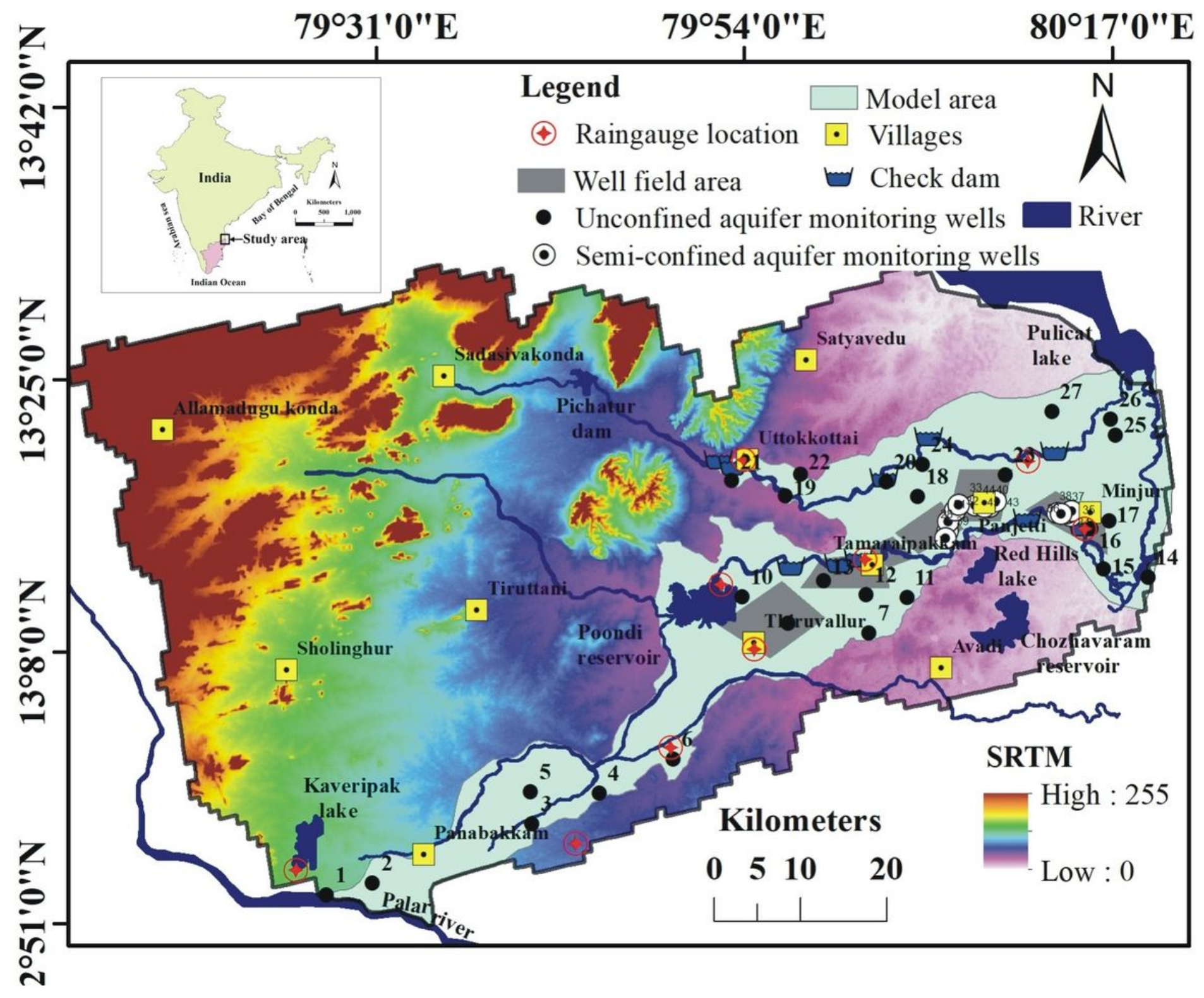

Figure 1

Location of the study area Note: The designations employed and the presentation of the material on this map do not imply the expression of any opinion whatsoever on the part of Research Square concerning the legal status of any country, territory, city or area or of its authorities, or concerning the delimitation of its frontiers or boundaries. This map has been provided by the authors. 

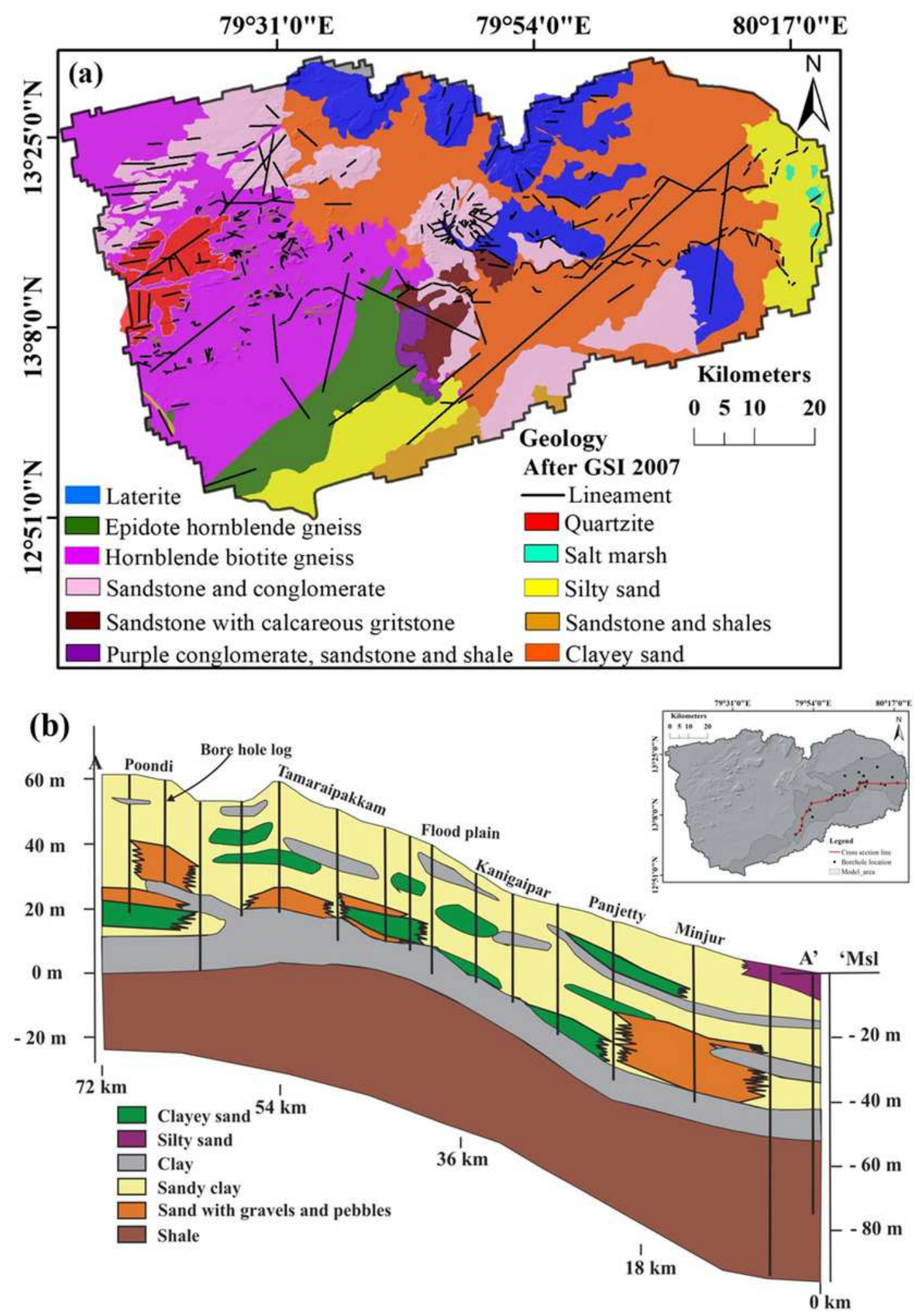

\section{Figure 2}

(a) Geology of the study area (b) West to east geological cross section along A-A' Note: The designations employed and the presentation of the material on this map do not imply the expression of any opinion whatsoever on the part of Research Square concerning the legal status of any country, territory, city or area or of its authorities, or concerning the delimitation of its frontiers or boundaries. This map has been provided by the authors. 


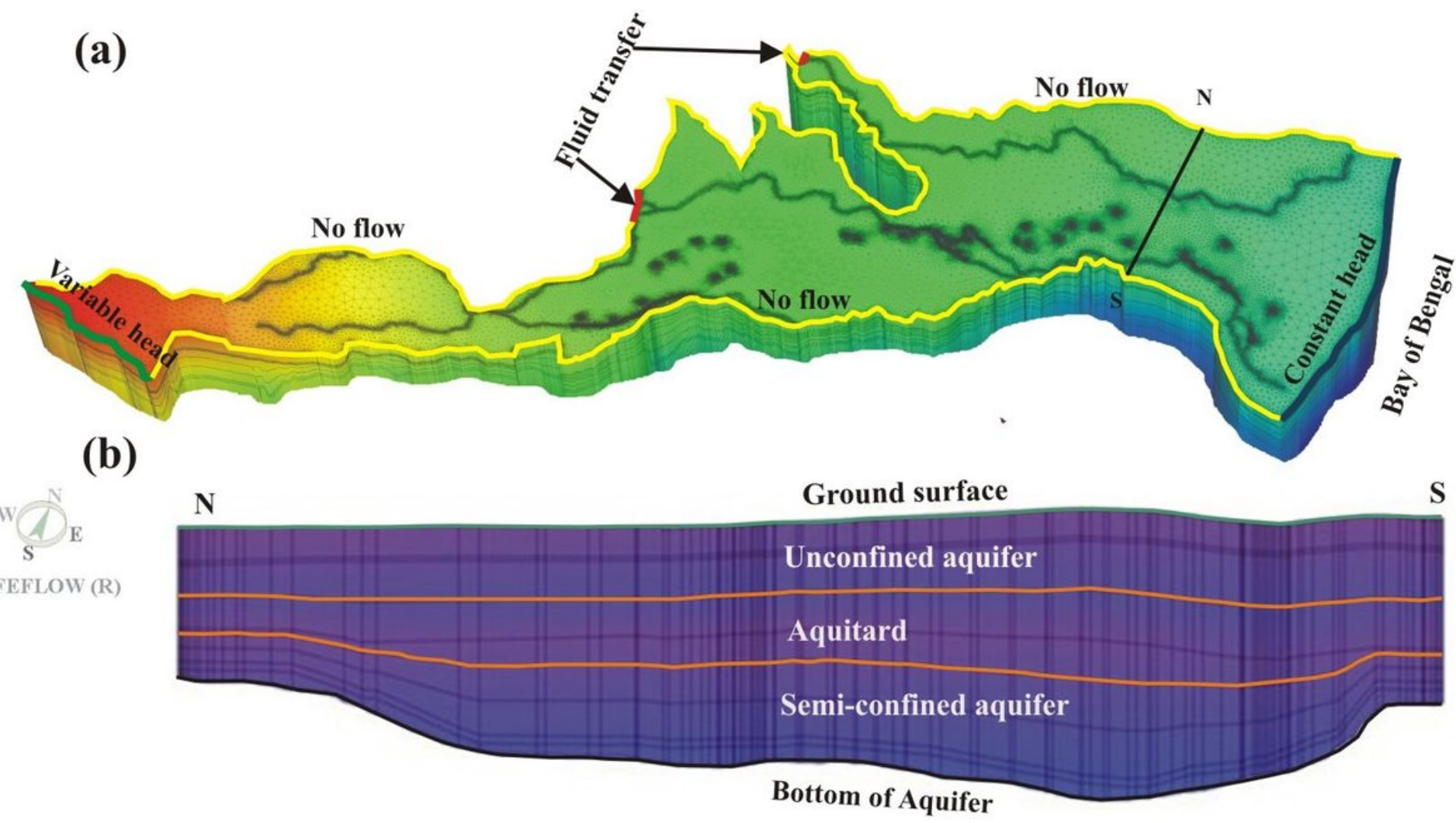

\section{Figure 3}

(a) Perspective view of the three-dimensional discretization of the aquifer system (b) North south cross section Note: The designations employed and the presentation of the material on this map do not imply the expression of any opinion whatsoever on the part of Research Square concerning the legal status of any country, territory, city or area or of its authorities, or concerning the delimitation of its frontiers or boundaries. This map has been provided by the authors. 

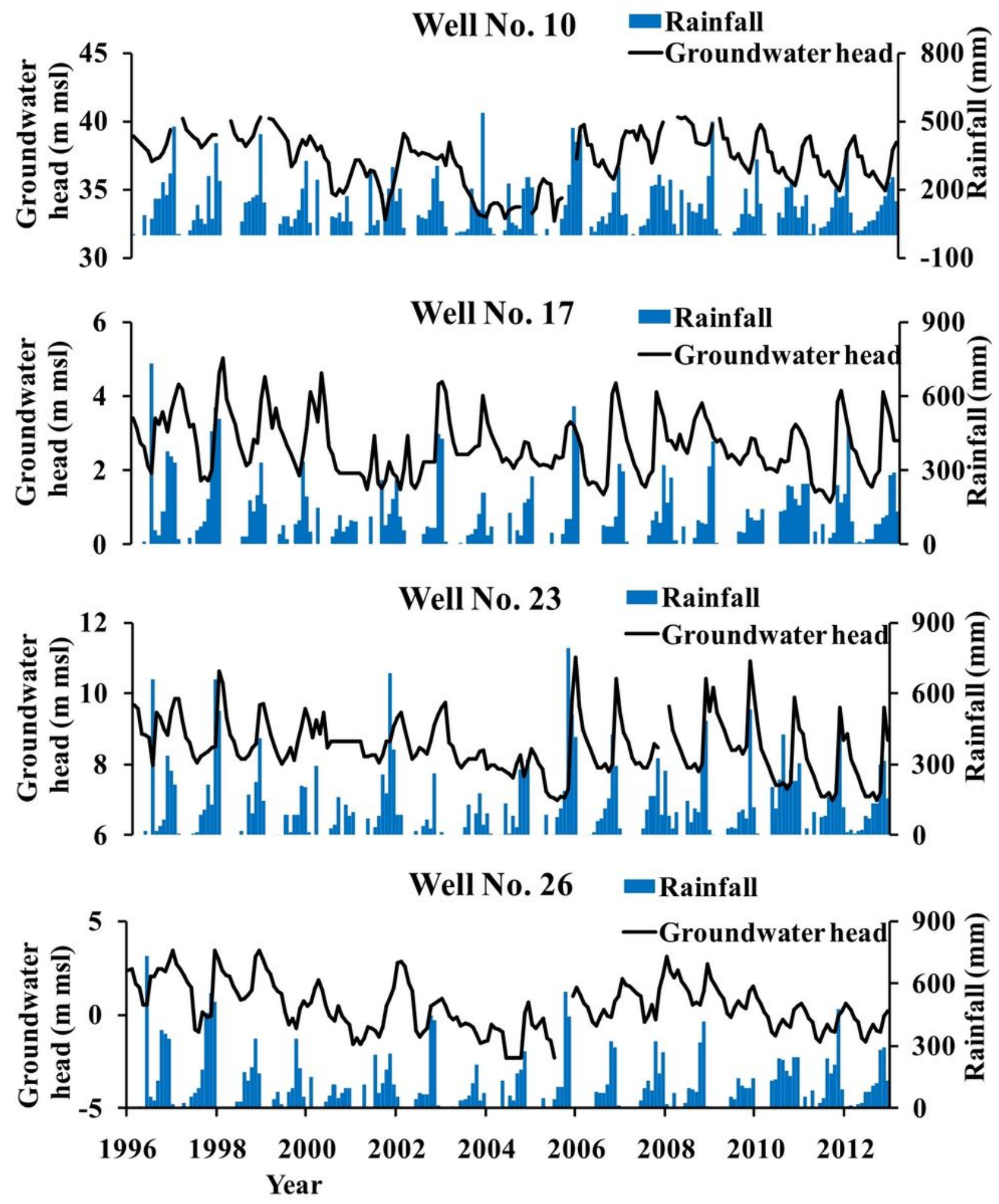

Figure 4

Monthly variations in rainfall and groundwater head in the unconfined aquifer 

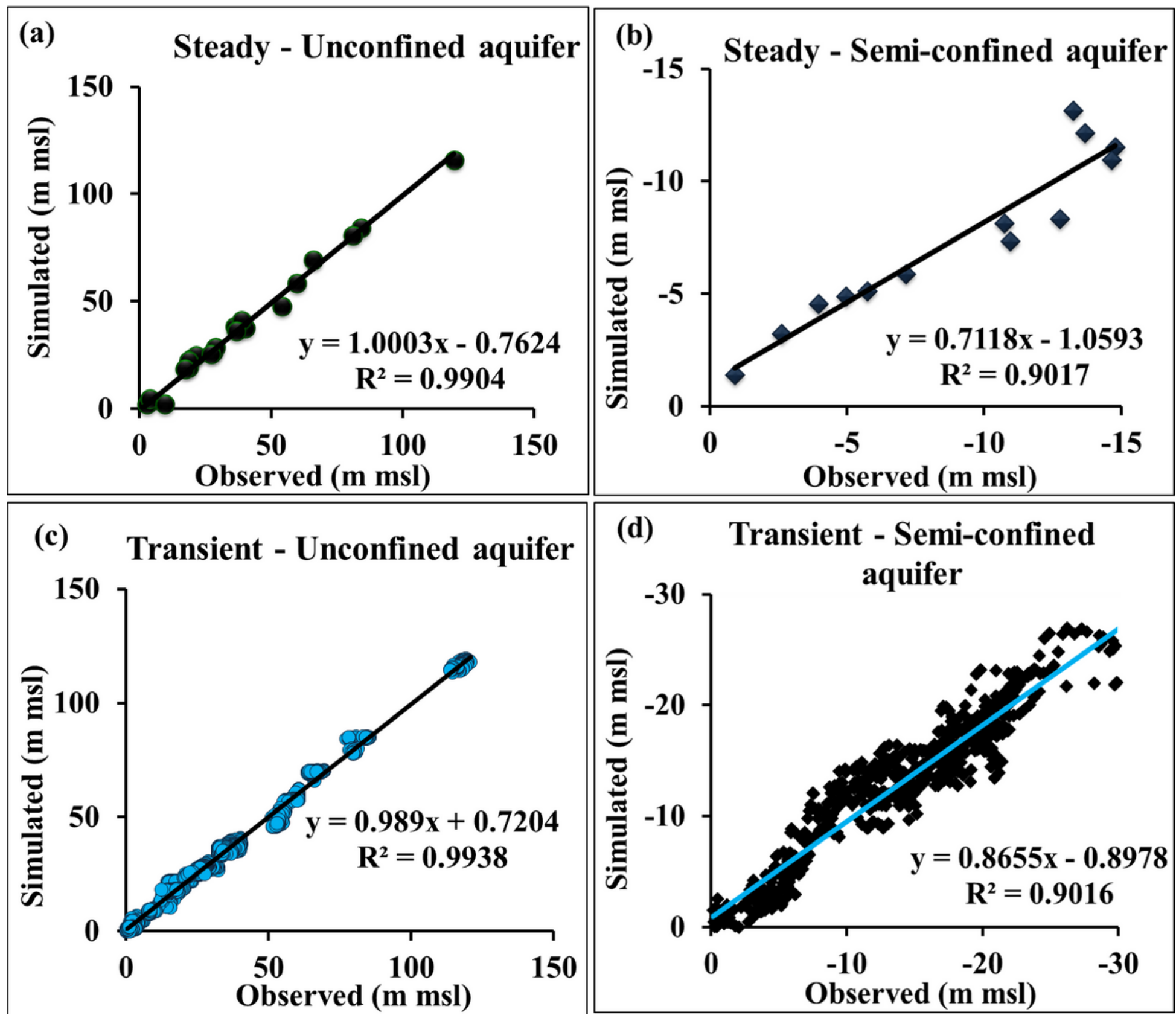

Figure 5

Observed and simulated groundwater heads in steady state (a) unconfined aquifer (b) semi-confined aquifer, in transient state (c) unconfined aquifer (d) semi-confined aquifer 
(A)

Simulated groundwater head

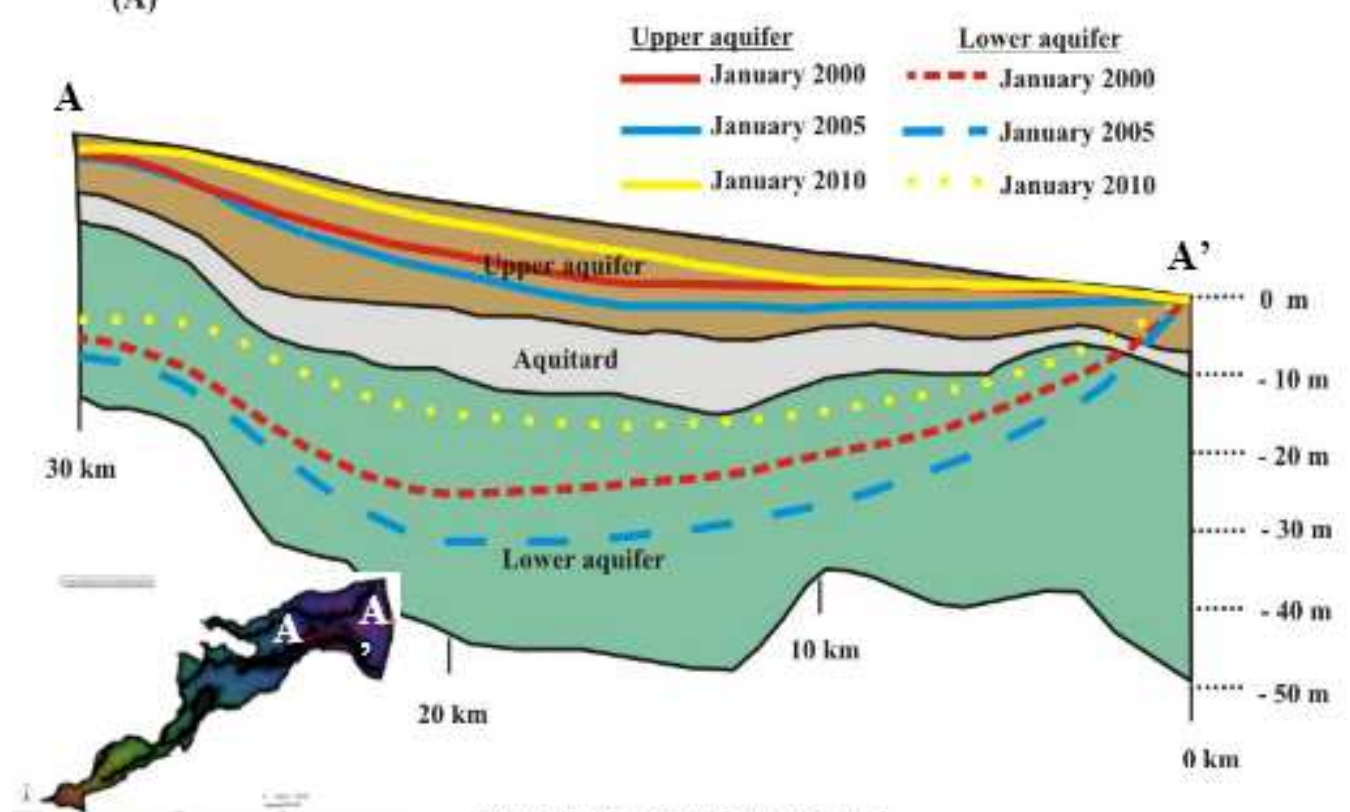

Simulated groundwater head

(B)

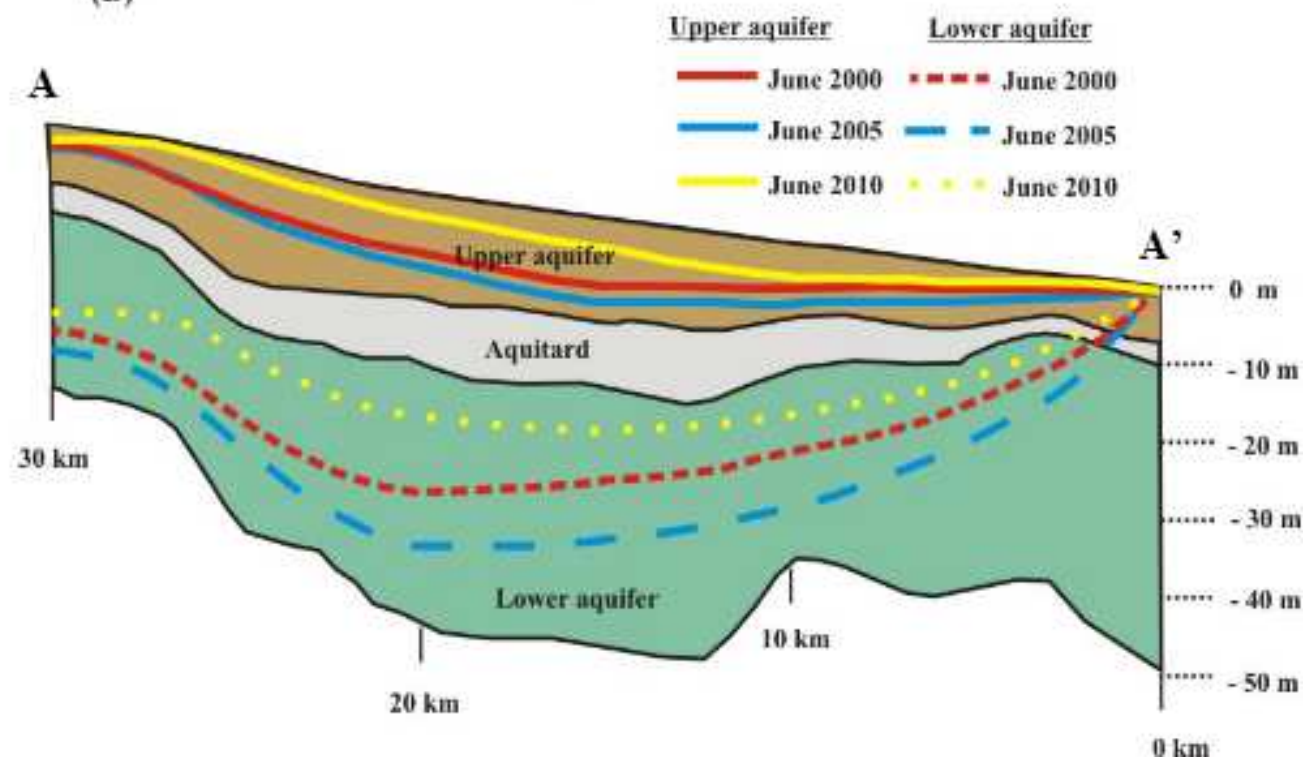

Figure 6

Simulated groundwater head showing in the aquifer cross-section (a) January and (b) June for the years 2000, 2005 and 2010 Note: The designations employed and the presentation of the material on this map do not imply the expression of any opinion whatsoever on the part of Research Square concerning the legal status of any country, territory, city or area or of its authorities, or concerning the delimitation of its frontiers or boundaries. This map has been provided by the authors. 


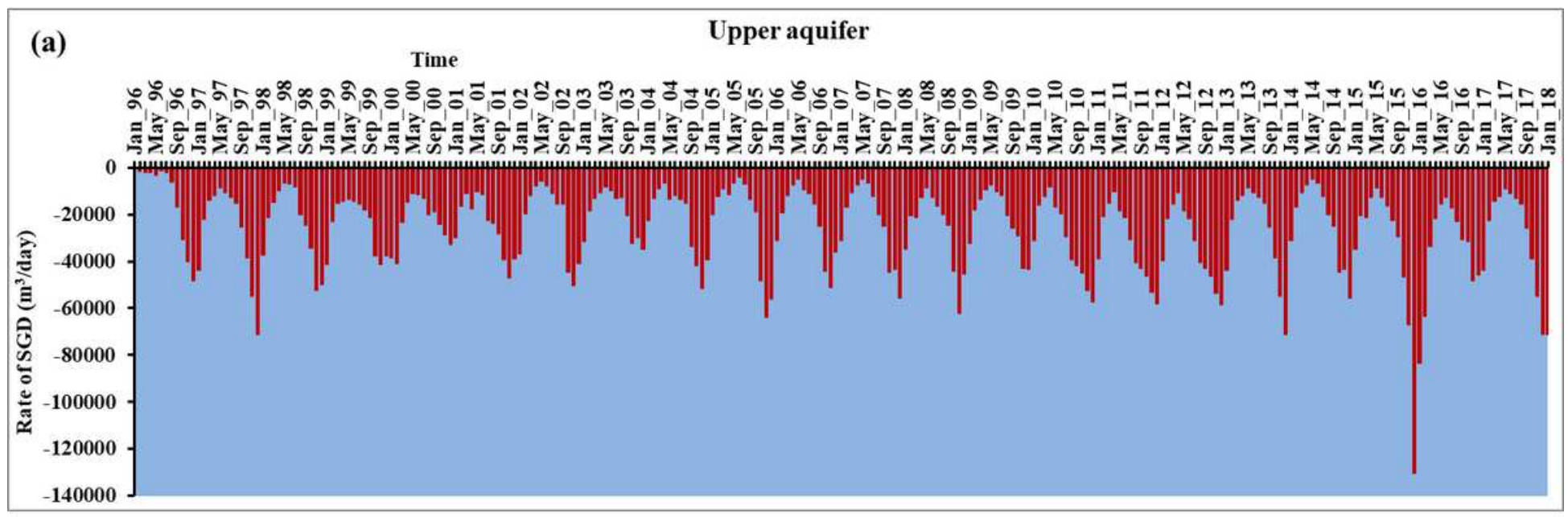

(b)

Lower aquifer

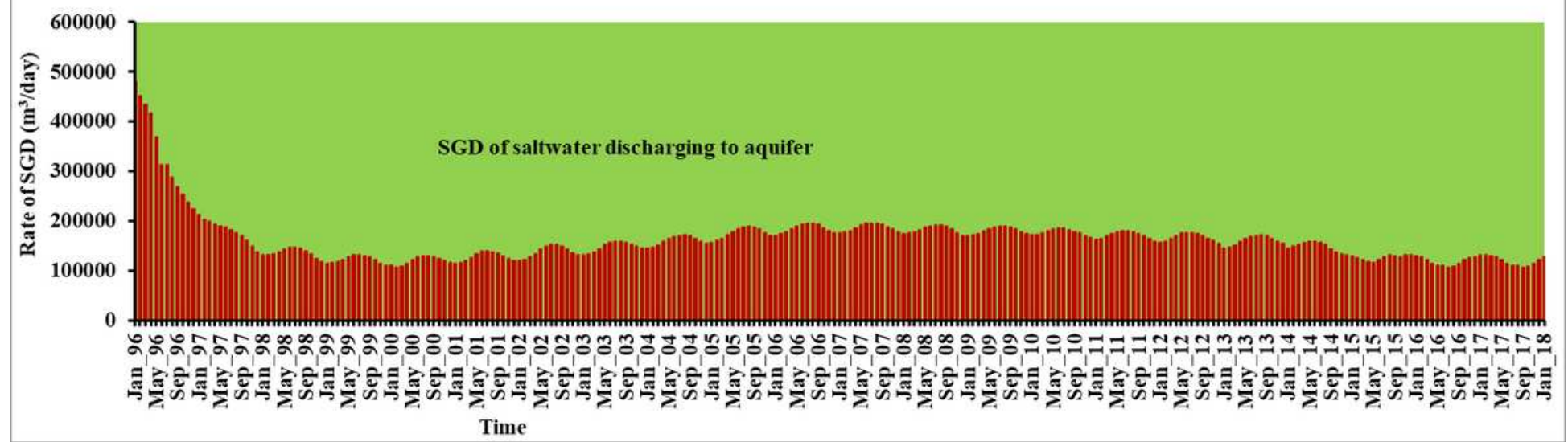

\section{Figure 7}

Temporal variations of total SGD along the eastern boundary (a) unconfined aquifer (b) semi-confined aquifer
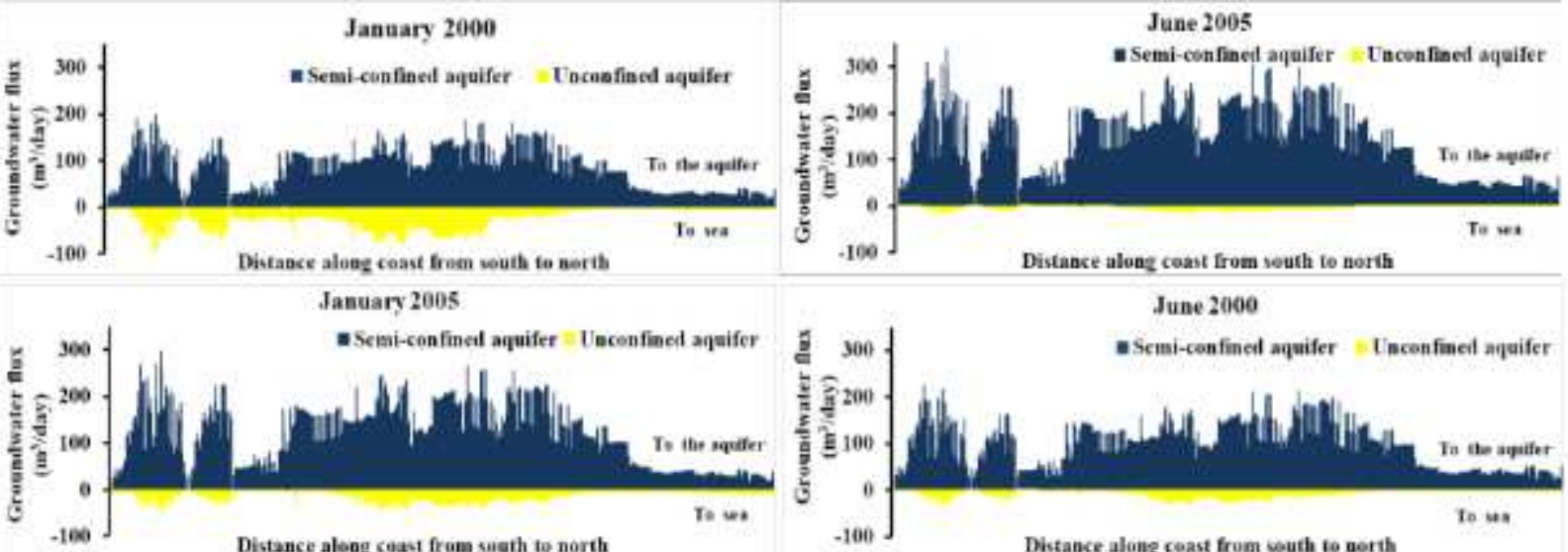

June 2000
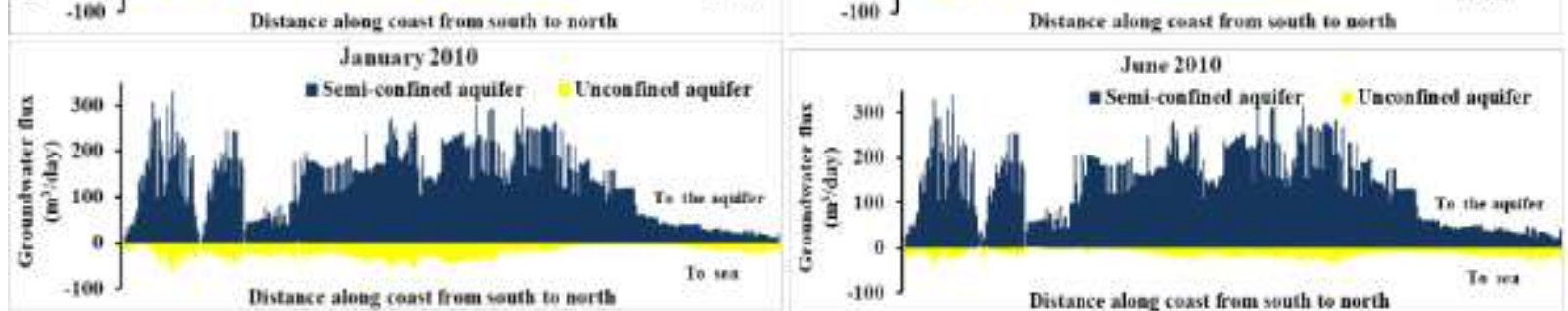
Figure 8

Total groundwater flux along the eastern boundary (a) January 2000, 2005 and 2010 (b) June 2000, 2005 and 2010

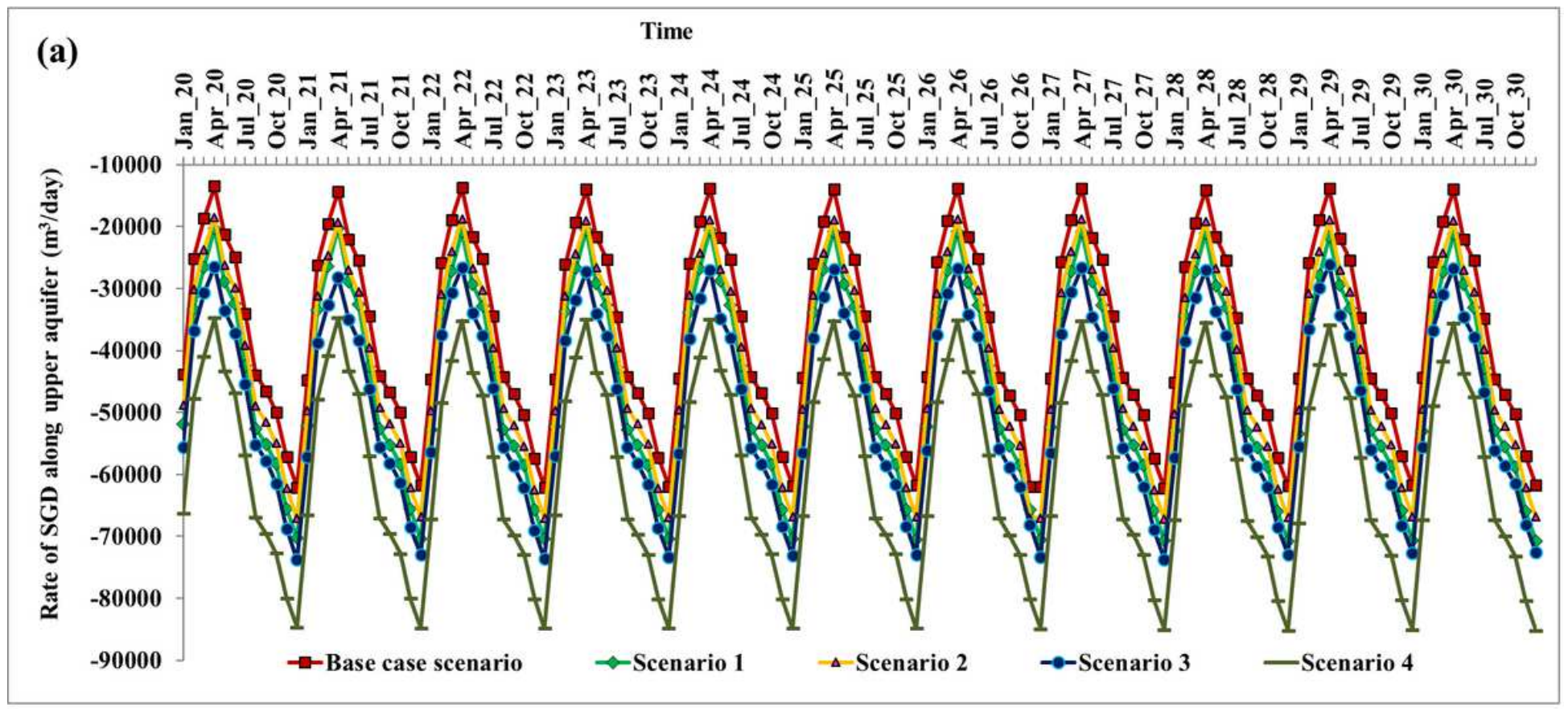

(b)
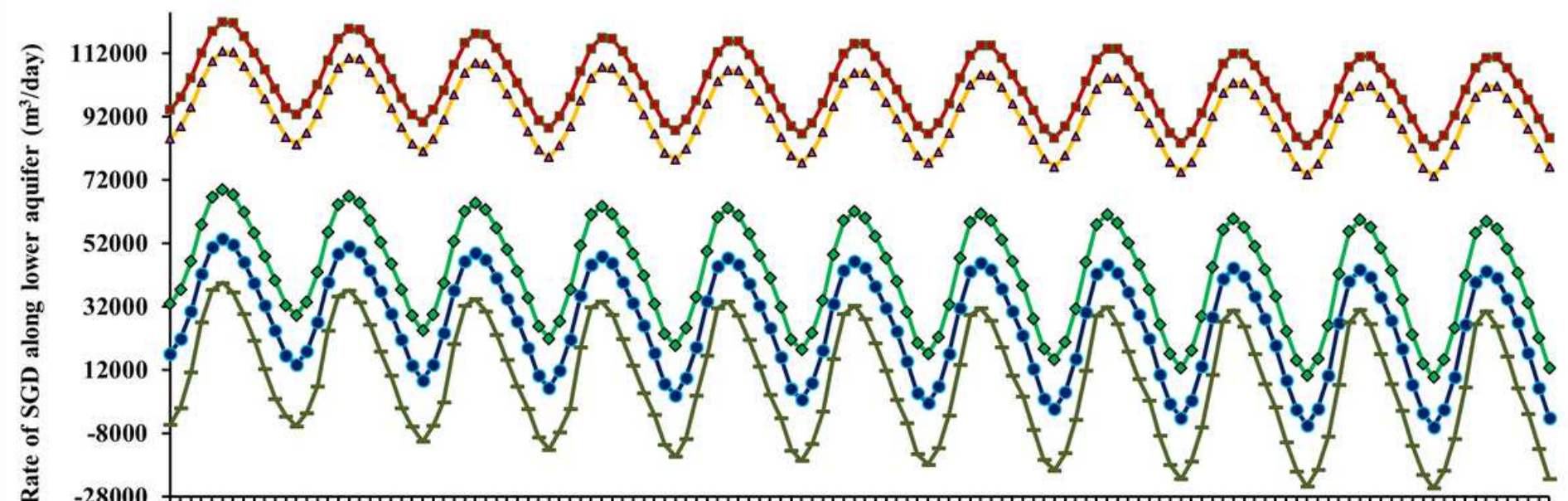

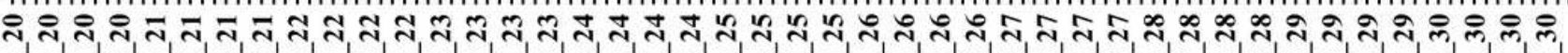

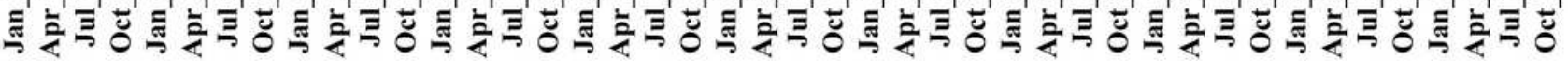

Time

Figure 9

Predicted rate of SGD along the eastern boundary in the (a) unconfined aquifer (b) semi-confined aquifer 